\title{
Secondary aerosol formation promotes water uptake by organic-rich wildfire haze particles in equatorial Asia
}

\author{
Jing Chen ${ }^{1}$, Sri Hapsari Budisulistiorini ${ }^{1}$, Takuma Miyakawa ${ }^{2}$, Yuichi Komazaki ${ }^{2}$, and Mikinori Kuwata ${ }^{1,3,4}$ \\ ${ }^{1}$ Earth Observatory of Singapore, Nanyang Technological University, Singapore, Singapore \\ ${ }^{2}$ Research and Development Center for Global Change, Japan Agency for Marine-Earth Science and Technology, \\ Yokosuka, Japan \\ ${ }^{3}$ Asian School of Environment, Nanyang Technological University, Singapore, Singapore \\ ${ }^{4}$ Campus for Research Excellence and Technological Enterprise (CREATE) program, Singapore, Singapore
}

Correspondence: Jing Chen (chen.jing@ntu.edu.sg) and Mikinori Kuwata (kuwata@ntu.edu.sg)

Received: 25 October 2017 - Discussion started: 26 October 2017

Revised: 30 April 2018 - Accepted: 20 May 2018 - Published: 4 June 2018

\begin{abstract}
The diameter growth factor (GF) of $100 \mathrm{~nm}$ haze particles at $85 \%$ relative humidity $(\mathrm{RH})$ and their chemical characteristics were simultaneously monitored at Singapore in October 2015 during a pervasive wildfire haze episode that was caused by peatland burning in Indonesia. Non-refractory submicron particles $\left(\mathrm{NR}-\mathrm{PM}_{1}\right)$ were dominated by organics (OA; approximating $77.1 \%$ in total mass), whereas sulfate was the most abundant inorganic constituent (11.7\% on average). A statistical analysis of the organic mass spectra showed that most organics $(36.0 \%$ of NR$\mathrm{PM}_{1}$ mass) were highly oxygenated. Diurnal variations of GF, number fractions of more hygroscopic mode particles, mass fractions of sulfate, and mass fractions of oxygenated organics (OOA) synchronized well, peaking during the day. The mean hygroscopicity parameter $(\kappa)$ of the haze particles was $0.189 \pm 0.087$, and the mean $\kappa$ values of organics were $0.157 \pm 0.108\left(\kappa_{\text {org }}\right.$, bulk organics $)$ and $0.266 \pm 0.184\left(\kappa_{\mathrm{OOA}}\right.$, OOA), demonstrating the important roles of both sulfate and highly oxygenated organics in the hygroscopic growth of organics-dominated wildfire haze particles. $\kappa_{\text {org }}$ correlated with the water-soluble organic fraction insignificantly, but it positively correlated with $f_{44}$ (fraction of the ion fragment at $m / z 44$ in total organics) $(R=0.70)$, implying the oxygenation degree of organics could be more critical for the water uptake of organic compounds. These results further suggest the importance of sulfate and secondary organic aerosol formation in promoting the hygroscopic growth of wildfire haze particles. Further detailed size-resolved as well as molecularlevel chemical information about organics is necessary for
\end{abstract}

the profound exploration of water uptake by wildfire haze particles in equatorial Asia.

\section{Introduction}

In the last few decades, wildfire haze has periodically raged throughout equatorial Asian countries (Page et al., 2002; van der Werf et al., 2010; Field et al., 2016; Koplitz et al., 2016), resulting in billions of dollars of economic losses as well as thousands of premature deaths (Johnston et al., 2012; Marlier et al., 2013). The increasing wildfire activity is associated with the recent rapid change in land use for agricultural development, including industrial plantations over peatland (Page et al., 2009; Marlier et al., 2015; Spracklen et al., 2015). Such developments are accompanied by the drainage of water of pristine peat swamp forest, making the tropical peatland susceptible to fire (Langner et al., 2007; Konecny et al., 2016). The occurrence of peatland fires is closely related to El Niño-induced droughts (Page et al., 2002; Field et al., 2016). Enhanced peatland fires have been observed during intense El Niño years, including 1997, 2006, and 2015 (Page et al., 2002; van der Werf et al., 2010; Stockwell et al., 2016). In 1997, the peatland fire was of global concern, as the total carbon emission was estimated to equal 13-40\% of the year's annual global carbon emission from fossil fuels (Page et al., 2002). The recent equatorial Asian wildfire haze event in 2015 could rival the one in 1997 not only in terms of the hazards to human health but also the significant 
impacts on global climate (Crippa et al., 2016; Field et al., 2016; Huijnen et al., 2016; Koplitz et al., 2016; Stockwell et al., 2016). During September-October 2015, thick smoke from peatland fires blanketed equatorial Asia and released huge amounts of organic material and fine particulate matter (particulate matter of aerodynamic diameter below $2.5 \mu \mathrm{m}$, $\mathrm{PM}_{2.5}$ ) (Crippa et al., 2016; Koplitz et al., 2016), which is the leading cause of global air-pollution-related mortality (Kunii et al., 2002; World Health Organization, 2009; Johnston et al., 2012; Marlier et al., 2013; Lelieveld et al., 2015).

A previous study on the peatland fire event in 1997 has reported that the wildfire haze particles resulted in dramatic cooling effects on the atmospheric radiative budget, especially over the source region of Indonesia $\left(-150 \mathrm{~W} \mathrm{~m}^{-2}\right)$ and the tropical Indian Ocean $\left(-10 \mathrm{~W} \mathrm{~m}^{-2}\right.$ ) (Duncan et al., 2003). In addition to the subsequently affected shallow warm clouds and deep convection processes, the resultant abnormal rainfall in the adjacent tropical region and the extratropics was also confirmed by both satellite observations and model simulations (Rosenfeld, 1999). These studies demonstrate the importance of investigating aerosol-cloud-precipitation interactions of Indonesian wildfire haze particles, including water uptake properties of aerosol particles.

Previous studies on water uptake properties of aerosol particles stemming from Indonesian peatland fires are controversial. On one hand, laboratory studies have demonstrated that fresh Indonesian peat burning particles are weakly hygroscopic and almost inactive as cloud condensation nuclei (CCN) (Chand et al., 2005; Dusek et al., 2005; Chen et al., 2017). On the other hand, a field observation showed that the wildfire haze particles were highly hygroscopic during the 1997 Indonesian peatland fires (Gras et al., 1999). Such discrepancies impede reliable evaluations of the effects on regional and global climate changes driven by Indonesian wildfire haze particles (Lin et al., 2013; Reid et al., 2013). The cause of the discrepancies needs to be understood quantitatively in comparison with the chemical composition of particles.

Aerosol particles emitted from wildfires are a mixture of inorganic and organic compounds, which complicates their water uptake properties (Carrico et al., 2008, 2010; Petters et al., 2009; Hallar et al., 2013; Lathem et al., 2013). Water uptake properties of inorganic salts, such as ammonium sulfate and ammonium nitrate, are well known, yet the hygroscopic behavior of organic compounds or organic-inorganic mixtures is still difficult to predict due to the complex chemical composition of organics (OA) and the associated distinct affinity for water of a specific chemical constituent (Saxena et al., 1995; Gysel et al., 2004; Dinar et al., 2007; Petters and Kreidenweis, 2007; Carrico et al., 2010; Kristensen et al., 2012; Marsh et al., 2017). For instance, experimental and modeling studies have shown that the water uptake by watersoluble matter is governed by the inorganic fraction, whereas the hygroscopic properties of inorganics can be altered substantially by the presence of organics (Saxena et al., 1995;
Dick et al., 2000). In general, with the increase in the organic fraction, the water uptake by wildfire particles has presented an overall decreasing trend (Mircea et al., 2005; Carrico et al., 2010), evidencing the high sensitivity of particle water uptake to organic fractions. The high sensitivity to organic fractions has been observed, as inorganic species are much more hygroscopic than most organic compounds. However, the roles of inorganic and organic species in water uptake by Indonesian peatland burning particles have rarely been investigated (Dusek et al., 2005; Chen et al., 2017).

Water uptake properties of organic compounds have also been demonstrated to be important especially when the chemical composition of aerosol particles is dominated by organics. Such cases have been frequently observed in particles emitted from wildfires (Petters et al., 2009; Carrico et al., 2010; Cubison et al., 2011; Hallar et al., 2013; Chen et al., 2017). Both theoretical and experimental studies demonstrated that water-soluble organic matter (WSOM) plays the key role in determining the water uptake by organic compounds (Peng et al., 2001; Gysel et al., 2004; Petters and Kreidenweis, 2007; Carrico et al., 2008; Petters et al., 2009; Lathem et al., 2013; Chen et al., 2017). For instance, freshly emitted peat burning particles are known to contain a small fraction of WSOM, which explains their limited hygroscopicity (Chen et al., 2017). Chemical aging and oxidation of organic compounds in both gas and particle phases could alter the water uptake properties of aerosol particles in a wildfire plume (Gras et al., 1999; Petters et al., 2009; Rose et al., 2010; Cubison et al., 2011). These chemical processes in the atmosphere enhance the fractions of highly oxygenated organics (OOA) and polar species, which are typically water soluble (Duplissy et al., 2008, 2011; Jimenez et al., 2009; Chang et al., 2010; Massoli et al., 2010; Cubison et al., 2011; Cerully et al., 2015). Although such chemical transformation and corresponding changes in hygroscopicity have been observed in wildfire particles in both the laboratory and the field (Petters et al., 2009; Massoli et al., 2010; Rose et al., 2010; Cubison et al., 2011; Duplissy et al., 2011), the importance of these processes for water uptake properties has never been investigated for peatland burning particles in the equatorial Asian region.

In this work, we investigated the relationships between water uptake properties and the chemical composition of aerosol particles in a tropical peatland fire haze in October 2015 by conducting atmospheric observations in Singapore. We quantified water uptake properties using the $\mathrm{Hu}-$ midified Tandem Differential Mobility Analyzer (HTDMA). In parallel, particle chemical composition was characterized in real time using the Aerodyne time-of-flight aerosol chemical speciation monitor (ToF-ACSM). Furthermore, watersoluble organic carbon (WSOC) and elemental carbon (EC) contents were quantified by an offline analysis of ambient $\mathrm{PM}_{2.5}$ filter samples. The data from these measurements were combined to explore how the water uptake properties of tropical peatland burning particles are regulated. 


\section{Observation}

\subsection{Field campaign}

The field observation was conducted at the campus of Nanyang Technological University (NTU), Singapore $\left(1^{\circ} 20^{\prime} 41 \mathrm{~N}, 103^{\circ} 40^{\prime} 53 \mathrm{E}\right)$, during October 2015 . The campus is located $20 \mathrm{~km}$ away from the city center and surrounded by a secondary tropical forest and grassland. The site is located $0.8 \mathrm{~km}$ away from a highway, and a petrochemical complex (Jurong Island) is located approximately $8 \mathrm{~km}$ to the south. In September-October 2015, the observation site encountered severe transboundary haze pollution that was caused by recurring Indonesian peatland fires, dominated by the smoldering combustion of underground organic-rich peat soils and mixed surface vegetation burning (Page et al., 2009; Field et al., 2016; Jayaranthe et al., 2018). Particles emitted from the wildfires had experienced for approximately 1-4 days atmospheric aging processes before arriving at Singapore (Fig. S1 in the Supplement).

The observation was performed in an air-conditioned room, with the room temperature maintained at $22^{\circ} \mathrm{C}$. A cyclone (URG-2000-30EN PM P.5 $_{2}$, URG) was employed for ambient aerosol sampling at a flow rate of $16.67 \mathrm{~L} \mathrm{~min}^{-1}$. The inlet was fixed on the rooftop, which was located approximately $10 \mathrm{~m}$ above the ground. The sample air was split into several flows for measurements with different instruments after drying by diffusion dryers (the relative humidity, $\mathrm{RH}$, of the sample flow was below $30 \%$ ). During the observation, particle number size distribution, chemical composition, and hygroscopic growth were monitored.

\subsection{Particle water uptake measurements}

Water uptake properties were measured using the HTDMA system (Chen et al., 2017). Briefly, the sampled particles were desiccated using a diffusion dryer (model 42000, Brechtel Manufacturing, Inc.), and the resulting dry polydisperse particles were classified by the first differential mobility analyzer (DMA, model 3081, TSI Inc.). The DMA selects particles of a specific mobility diameter $\left(D_{0}\right)$, which was fixed at $100 \mathrm{~nm}$ during the observation. The classified particles were humidified to $\mathrm{RH}=85 \%$ using Nafion tubings (MD-110-12S-4, Perma Pure) operated under a controlled RH condition. The particle residence time in the humidifier was approximately $10 \mathrm{~s}$. The variation in $\mathrm{RH}$ was $\pm 0.5 \%$ (peak to peak). The resulting size distribution of humidified particles was measured by the second DMA coupled with a condensation particle counter (CPC, model 3775, TSI Inc.). The diameter growth factor (GF) parameter, $g$, which is defined as the ratio of the particle diameter after humidification at a conditioned $\mathrm{RH}\left(D_{\mathrm{p}}(\mathrm{RH})\right)$ to the initial dry size $\left(D_{0}\right)$ (i.e., $\left.g=D_{\mathrm{P}}(\mathrm{RH}) / D_{0}\right)$, was calculated from the HTDMA data. Hygroscopicity parameter, $\kappa$, was derived from the corresponding $g$ at a given RH and $D_{0}$ using the following equation (Petters and Kreidenweis, 2007):

$\kappa=\left(g^{3}-1\right) \cdot\left(\frac{1}{\mathrm{RH}} \cdot \exp \left(\frac{4 \sigma_{\mathrm{s} / \mathrm{a}} \cdot M_{\mathrm{w}}}{\rho_{\mathrm{w}} \cdot R \cdot T \cdot D_{0} \cdot g}\right)-1\right)$,

where $\sigma_{\mathrm{s} / \mathrm{a}}$ is the surface tension of the solution/air interface $\left(0.0718 \mathrm{~N} \mathrm{~m}^{-1}\right.$ at $\left.25^{\circ} \mathrm{C}\right) ; M_{\mathrm{W}}$ and $\rho_{\mathrm{W}}$ are the molecular weight $\left(0.018 \mathrm{~kg} \mathrm{~mol}^{-1}\right)$ and density of water $\left(1 \times 10^{3} \mathrm{~kg} \mathrm{~m}^{-3}\right)$, respectively; $R$ is the universal gas constant $\left(8.31 \mathrm{~J} \mathrm{~K}^{-1} \mathrm{~mol}^{-1}\right)$; and $T$ is the absolute temperature (298 K). The HTDMA calibration results with $150 \mathrm{~nm}$ ammonium sulfate particles are shown in Fig. S2, demonstrating the validity of our instrument. Further details about the HTDMA are available in Chen et al. (2017).

\subsection{Aerosol chemical analysis}

The ToF-ACSM (Aerodyne Inc.) was utilized to measure the chemical composition of non-refractory submicron particles $\left(\mathrm{NR}-\mathrm{PM}_{1}\right)$, including organics (OA), sulfate $\left(\mathrm{SO}_{4}^{2-}\right)$, nitrate $\left(\mathrm{NO}_{3}^{-}\right)$, ammonium $\left(\mathrm{NH}_{4}^{+}\right)$, and chloride $\left(\mathrm{Cl}^{-}\right)$(Fröhlich et al., 2013). The ToF-ACSM sampled particles that were desiccated by a Nafion tubing. The organic mass spectra measured by the ToF-ACSM were analyzed in detail using the multilinear engine (ME-2 solver) software (Canonaco et al., 2013). Four specific types of OA were identified: hydrocarbon-like OA (HOA), peat burning OA (PBOA), non-peat biomass burning OA (briefly BBOA), and oxygenated OA (OOA). The HOA factor was mainly contributed by primary sources, such as the combustion emissions from fossil fuel (e.g., related to traffic, shipping, and industrial use), excluding the influence of biomass burning. The PBOA and BBOA factors were attributed to the long-range transport from Indonesian peatland fires, and the two OA factors were well separated. Details about the ToF-ACSM measurements and data analysis are provided in Budisulistiorini et al. (2018).

$\mathrm{PM}_{2.5}$ filter samples for chemical analysis were also collected using filter holders (BGI Inc.). The samples were collected for $24 \mathrm{~h}$ using $47 \mathrm{~mm}$ (diameter) quartz-fiber filters. The sampling started and ended at 08:00 LT (local time). The collected samples were analyzed for bulk OC, EC, and WSOC. All the quartz-fiber filters were prebaked at $900^{\circ} \mathrm{C}$ for $3 \mathrm{~h}$ before sampling, after which they were stored in a refrigerator $\left(-20^{\circ} \mathrm{C}\right)$ until analysis. For each sampling, a backup quartz-fiber filter was used to account for the potential influence of gas-phase organic components on the particulate organics collected on the front quartz-fiber filter (Turpin et al., 1994). The method assumes that all the particulate OC is collected by the front filter, while the gas-phase $\mathrm{OC}$ is collected equally on both front and back filters. Subtraction of the OC loading on the back filter (i.e., gas-phase OC) from that on the front one allows quantification of particulate $\mathrm{OC}$ (i.e., corrected OC). 
Concentrations of $\mathrm{OC}$ and EC were determined by thermal-optical reflectance analysis (Chow et al., 1993) using the Sunset Laboratory OC/EC analyzer, following the IMPROVE-A protocol. WSOC was quantified with the Sievers 800 total organic carbon (TOC) analyzer following extraction of part of a filter sample $(8 \mathrm{~mm} \varphi)$ by $10 \mathrm{~mL}$ of HPLC-grade water. An orbital shaker was operated for $21 \mathrm{~h}$ for the extraction, and the subsequent solutions were filtered with syringe filters (pore size of $0.2 \mu \mathrm{m}$ ).

\subsection{Particle number size distribution}

Particle number size distributions were measured using a NanoScan SMPS nanoparticle sizer (NanoScan-SMPS, model 3910, TSI Inc.) and an optical particle sizer (OPS, model 3330, TSI Inc.). The detected particle sizes ranged from 11.5 to $365.2 \mathrm{~nm}$ (NanoScan-SMPS) in mobility size and 0.3 to $10 \mu \mathrm{m}$ (OPS) in optical size. Both instruments sampled particles desiccated by a diffusion dryer (model 42000, Brechtel Manufacturing, Inc.). The time resolution of both instruments was $1 \mathrm{~min}$.

\section{HTDMA data analysis}

\subsection{Classification of three hygroscopic modes}

Figure 1 shows the HTDMA data averaged over the entire observation period. The mean normalized particle size distribution after humidification at $85 \% \mathrm{RH}$ has spanned a few different modes, reflecting mixing states of ambient wildfire haze particles observed at Singapore (Bougiatioti et al., 2016; Ogawa et al., 2016). For particles in a specific hygroscopic mode, $i$, with $g_{1, i}<\mathrm{GF}<g_{2, i}$, the number fraction of this mode $\left(\mathrm{nf}_{i}\right)$ was derived from the measured probability density function of $g$ (i.e., $\left.c\left(g, D_{0}\right)\right)$ as $n f_{i}=\int_{g_{1, i}}^{g_{2, i}} c\left(g, D_{0}\right) d g$. The corresponding mean GF $\left(g_{\text {mean }, i}\right)$ was calculated from $g_{\text {mean }, i}=\frac{1}{\mathrm{nf}_{i}} \int_{g_{1, i}}^{g_{2, i}} g c\left(g, D_{0}\right) d g$ (Gysel et al., 2009). The equivalent values of $\kappa$ for mode $i$ were obtained from $g_{\text {mean, } i}$ using Eq. (1).

The observed $100 \mathrm{~nm}$ dry particles were categorized into the following three groups based on their hygroscopic properties at $\mathrm{RH}=85 \%$ (temporal variation of the multimodal size distribution patterns are shown in Fig. S3), facilitating the analysis of heterogeneity of particle chemical composition.

1. Nearly non-hygroscopic or weakly hygroscopic particles $(0 \leq \kappa<0.1 ; g<1.15)$ : particles are predominantly composed of black carbon (BC) and non-polar hydrocarbon-like organic compounds (Peng et al., 2001; Gysel et al., 2007; Kreidenweis et al., 2008).

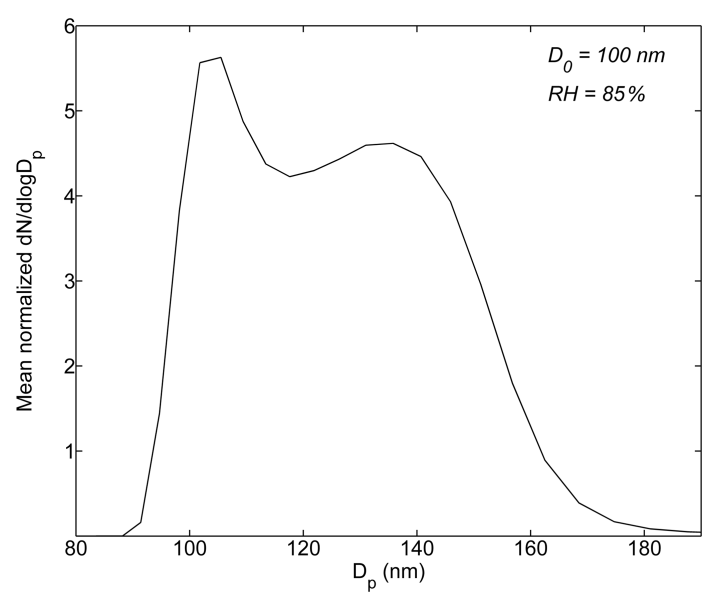

Figure 1. Normalized particle number size distribution $\left(\left(\mathrm{d} N / \mathrm{d} \log D_{\mathrm{p}}\right) / N\right)$ after humidification averaged over the entire haze observation period.

2. Moderately hygroscopic particles $(0.1 \leq \kappa<0.2$; $1.15 \leq g<1.27)$ : they could contain hygroscopic organics (e.g., carboxylic acids and levoglucosan) and/or mixtures of non-, less, and more hydrophilic compounds (e.g., BC, fatty acids, and/or humiclike substances mixed with ammonium sulfate or levoglucosan-like species) (Peng et al., 2001; Chan and Chan, 2003; Gysel et al., 2004, 2007; Chan et al., 2005; Petters and Kreidenweis, 2007).

3. More hygroscopic particles $(\kappa \geq 0.2 ; g \geq 1.27)$ : aerosol particles contain inorganic salts as well as some more hygroscopic organic species such as multifunctional organic acids (Peng et al., 2001; Carrico et al., 2008; Duplissy et al., 2011; Ogawa et al., 2016).

In addition, the volume-weighted mean growth factor, GF, was also calculated using $c\left(g, D_{0}\right)$ (Gysel et al., 2009):

$\mathrm{GF}=\left(\int_{0}^{\infty} g^{3} \cdot c\left(g, D_{0}\right) \cdot d g\right)^{1 / 3}$.

GF was employed to calculate the mean values of $\kappa$, which facilitated the comparison with chemical composition of aerosol particles.

\subsection{Effective $\kappa$ of organic compounds $\left(\kappa_{\text {org }}\right)$}

Water uptake properties of organic compounds were estimated using the Zdanovskii-Stokes-Robinson (ZSR) mixing rule, employing the observed values of $\kappa$ and chemical composition as input parameters. The ZSR mixing rule assumes that water uptake by a mixture of materials is additive of the water content retained by each chemical species (Stokes and Robinson, 1966). The rule also assumes that the volume change in the mixing of species within individual particles is 
almost negligible (Brechtel and Kreidenweis, 2000; Gysel et al., 2007; Petters and Kreidenweis, 2007):

$$
\begin{gathered}
\kappa=\sum_{i} \kappa_{i} \cdot \varepsilon_{i}=\kappa_{\mathrm{SNA}} \cdot \varepsilon_{\mathrm{SNA}}+\kappa_{\mathrm{org}} \cdot \varepsilon_{\mathrm{org}}+\kappa_{\mathrm{EC}} \cdot \varepsilon_{\mathrm{EC}} \\
\Leftrightarrow \kappa_{\mathrm{org}}=\frac{\kappa-\kappa_{\mathrm{SNA}} \cdot \varepsilon_{\mathrm{SNA}}-\kappa_{\mathrm{EC}} \cdot \varepsilon_{\mathrm{EC}}}{\varepsilon_{\mathrm{org}}},
\end{gathered}
$$

where $\kappa_{i}$ and $\varepsilon_{i}$ stand for the hygroscopicity parameter and the volume fraction of a specific component $i$ in dry particles, respectively. The subscript "SNA" represents the three major inorganic constituents of sulfate, nitrate, and ammonium; "org" denotes organic species; "EC" indicates elemental carbon.

Sulfate, ammonium, and nitrate were considered for inorganics, the majority of which were contributed by sulfate (see Table 2). Other materials, such as sea salt and crustal elements, were demonstrated to be neglected because they are relatively scarce in submicron wildfire haze particles in Southeast Asia (Balasubramanian et al., 2003; Keywood et al., 2003; See et al., 2006; Stockwell et al., 2016). Almost all the sulfate and nitrate were neutralized by ammonia, and these three most abundant inorganic constituents were combined and assumed as ammonium sulfate (i.e., $\left.\varepsilon_{\mathrm{SNA}}=\varepsilon_{\mathrm{SO}_{4}}+\varepsilon_{\mathrm{NO}_{3}}+\varepsilon_{\mathrm{NH}_{4}} \approx \varepsilon_{\mathrm{AS}}\right)$. Thus, the value of $\kappa_{\mathrm{SNA}}$ was considered to approximate the $\kappa$ value of ammonium sulfate under the condition when sulfate dominates inorganics (Gunthe et al., 2009; Chang et al., 2010; Ogawa et al., 2016). The elemental carbon is known as non-hygroscopic (i.e., $\kappa_{\mathrm{EC}} \approx 0$ ).

Values of densities are required to compute $\varepsilon_{i}$ from observed mass fractions. The mass fraction is taken as the firstorder approximation of the volume fraction, based on the hypothesis that the bulk particle density is similar to the densities of individual compounds when volume additivity is assumed (Kreidenweis et al., 2008; Gunthe et al., 2009; Hallquist et al., 2009). This hypothesis has been demonstrated to be acceptable when particles are composed primarily of organics and sulfate (Cross et al., 2007; King et al., 2007). The densities of ammonium sulfate and EC were assumed to be 1.77 and $1.80 \mathrm{~g} \mathrm{~cm}^{-3}$, respectively (Park et al., 2004; Bond and Bergstrom, 2006). The density of organics is known to vary depending on their elemental composition (Kuwata et al., 2012). The value was assumed as $1.40 \mathrm{~g} \mathrm{~cm}^{-3}$, which is a typical value for ambient organic aerosols (Hallquist et al., 2009).

The EC mass fraction of approximately $10.0 \%$ in submicron wildfire haze particles was utilized according to the time-averaged EC content in ambient $\mathrm{PM}_{2.5}$ filter samples (see Table 2). This assumption was based on the preconditions that the wildfire haze particles were homogeneously mixed in varied sizes and that there was no significant difference between BC and EC. It should be noted that some difference in chemical composition could have existed between particles quantified by the ToF-ACSM $\left(\mathrm{NR}-\mathrm{PM}_{1}\right)$ and HTDMA $(100 \mathrm{~nm})$. Although the data obtained by these two techniques are frequently combined for detailed analysis (e.g., Whitehead et al., 2016), the difference in particle size range along with the particle mixing state (Whitehead et al., 2014) can be a source of uncertainty for the following discussion in this work.

\section{$3.3 \kappa$ of oxygenated organic compounds $\left(\kappa_{\mathrm{OOA}}\right)$}

As described in Sect. 2.3, organics were numerically segregated to HOA, PBOA, BBOA, and OOA. The value of $\kappa_{\text {org }}$ can be calculated by a linear combination of contributions from segregated fractions (Petters and Kreidenweis, 2007; Chang et al., 2010):

$$
\begin{aligned}
\kappa_{\mathrm{Org}} & =v_{\mathrm{HOA}} \cdot \kappa_{\mathrm{HOA}}+v_{\mathrm{PBOA}} \cdot \kappa_{\mathrm{PBOA}}+v_{\mathrm{BBOA}} \cdot \kappa_{\mathrm{BBOA}} \\
& +v_{\mathrm{OOA}} \cdot \kappa_{\mathrm{OOA}},
\end{aligned}
$$

where $v_{i}$ stands for the volume fraction of component $i$ in all the organics.

Water uptake by a mixed particle is largely driven by the relative abundance of more or less hygroscopic component, and it is more sensitive to uncertainties in the hygroscopicity of more hygroscopic compounds than that of less hygroscopic compounds (Gysel et al., 2007). Hydrocarbon(-like) $\mathrm{OA}$ is known to be almost non-hygroscopic, leading to the estimation that the $\kappa$ value of HOA is 0 (Gysel et al., 2007; Gunthe et al., 2009; Chang et al., 2010). Water uptake by freshly emitted biomass burning particles is generally limited, especially compared with OOA (Carrico et al., 2010; Chang et al., 2010; Chen et al., 2017). Based on our previously measured $\kappa$ results of fresh Indonesian peatland burning particles, an overall mean value of $\kappa_{\mathrm{PBOA}}=0.04$ was used for the fresh PBOA factor, and $\kappa_{\mathrm{BBOA}}=0.06$ was applied for the non-peat BBOA factor with mixed vegetation burning mainly of acacia and fern species (Chen et al., 2017). Under these assumptions, $\kappa_{\mathrm{OOA}}$ can be calculated by the following equation:

$\kappa_{\mathrm{OOA}}=\left(\kappa_{\mathrm{Org}}-\kappa_{\mathrm{PBOA}} \cdot v_{\mathrm{PBOA}}-\kappa_{\mathrm{BBOA}} \cdot v_{\mathrm{BBOA}}\right) / v_{\mathrm{OOA}}$.

The density of OOA/PBOA/BBOA is required to calculate $v_{\mathrm{OOA}} / v_{\mathrm{PBOA}} / v_{\mathrm{BBOA}}$ using the ME-2-resolved corresponding mass concentration combined with the total volume concentration of the bulk OA derived from the ToF-ACSMobserved OA mass. The density of oxygenated organics was assumed to be $1.50 \mathrm{~g} \mathrm{~cm}^{-3}$ (as summarized in Table 1), which is a typical value for carboxylic and multifunctional organic acids (Saxena et al., 1995; Peng et al., 2001; Gysel et al., 2004; Carrico et al., 2010; Ogawa et al., 2016). According to the reported average density for common dry smoke particles (i.e., 1.20-1.40 $\mathrm{g} \mathrm{cm}^{-3}$; Reid et al., 2005), and considering the dominance of non-refractory organic material in fresh Indonesian peatland burning particles (Budisulistiorini et al., 2017), the densities of PBOA and non-peat BBOA were assumed to be 1.10 and $1.20 \mathrm{~g} \mathrm{~cm}^{-3}$, respectively. Detailed information on the parameters utilized for the $\kappa_{\text {org }}$ calculation is provided in Table 1. 


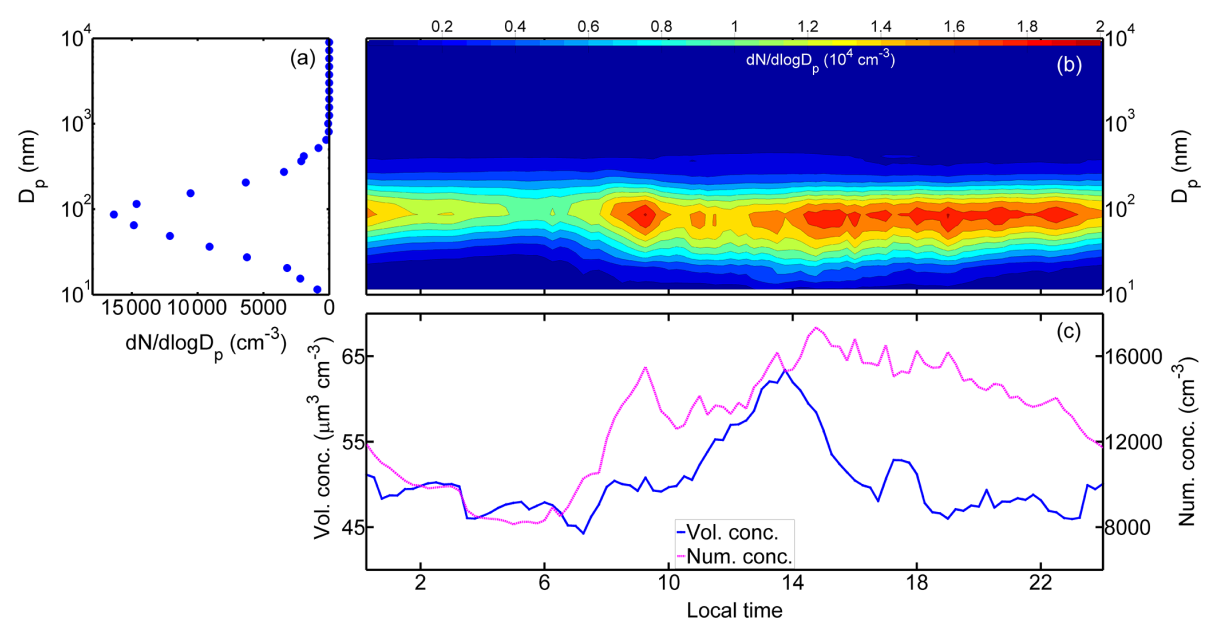

Figure 2. (a) The mean particle number size distribution $\left(\mathrm{d} N / \mathrm{d} \log D_{\mathrm{p}}, \mathrm{cm}^{-3}\right)$ during the ambient wildfire haze observations as well as the mean diurnal variations of (b) particle size distribution, (c) number concentration ("Num. conc.", $\mathrm{cm}^{-3}$, denoted by the magenta solid line), and volume concentration ("Vol. conc.", $\mu \mathrm{m}^{3} \mathrm{~cm}^{-3}$, as the blue line displayed) measured with NanoScan-SMPS (11.5-365.2 nm) and OPS $(419 \mathrm{~nm}-10 \mu \mathrm{m})($ local time, LT). High aerosol loading was commonly observed during the transboundary wildfire haze. Submicron particles in the size range of 30-200 $\mathrm{nm}$ dominated the total number concentration of wildfire haze particles.

Table 1. Summary of the hygroscopicity parameters $(\kappa)$ and material densities of different chemical constituents utilized in the theoretical $\kappa$ calculation with chemical data.

\begin{tabular}{llc}
\hline $\begin{array}{l}\text { Chemical } \\
\text { compounds }\end{array}$ & $\begin{array}{l}\text { Hygroscopicity } \\
\text { parameter, } \kappa\end{array}$ & $\begin{array}{c}\text { Density } \\
\left(10^{3} \mathrm{~kg} \mathrm{~m}^{-3}\right)\end{array}$ \\
\hline SNA $^{\mathrm{a}}$ & 0.59 & 1.77 \\
EC & 0 & 1.80 \\
PBOA & $0.04^{\mathrm{b}}$ & 1.10 \\
BBOA & $0.06^{\mathrm{b}}$ & 1.20 \\
OOA & $\kappa_{\text {OOA }}^{\mathrm{c}}$ & 1.50 \\
Bulk OA & $\kappa_{\text {Org }}^{\mathrm{c}}$ & 1.40 \\
\hline
\end{tabular}

${ }^{a}$ SNA includes all the sulfate, nitrate, and ammonium in submicron wildfire haze particles. ${ }^{b} \kappa$ values were assumed according to the mean $\kappa$ results derived from laboratory studies (Chen et al., 2017). ${ }^{\mathrm{c}} \kappa_{\mathrm{OOA}}$ and $\kappa_{\mathrm{Org}}$ were derived from ambient water uptake measurements and chemical data, in combination with the given parameters in Table 1, using the simplified algorithm introduced in Sect. 3.2 and 3.3.

\section{Results}

In this section, aerosol number size distribution (Fig. 2), chemical composition (Figs. 3 and 4), and hygroscopic properties of aerosol particles (Fig. 5) are described in addition to diurnal variations in these data (Fig. 6).

\subsection{Number size distribution of wildfire haze particles}

Figure 2a displays the time-averaged particle size distribution within the entire size range of $11.5 \mathrm{~nm}-10 \mu \mathrm{m}$ measured by NanoScan-SMPS combined with OPS. The NanoScanSMPS data were used for the fine particles $(11.5-365.2 \mathrm{~nm})$, and the overlapped size range of the OPS ( $338 \mathrm{~nm}$ size bin) was excluded from the analysis. The data in the remaining OPS size range $(419 \mathrm{~nm}-10 \mu \mathrm{m})$ were combined with the fine particle data. The temporal average size distribution presented a unimodal structure, in which the number mode diameter was located around $100 \mathrm{~nm}$. Particles in the range of $30-200 \mathrm{~nm}$ dominated the total particle number concentration, whereas particles larger than $600 \mathrm{~nm}$ accounted for a minor fraction (less than $4.0 \%$ on average; Figs. S4 and S5). This result suggests that in Singapore the wildfire haze particles were predominantly contributed by submicron particles, in line with the corresponding chemical characteristics obtained in previous studies (Balasubramanian et al., 2003; See et al., 2006).

Figure $2 b$ shows the mean diurnal cycle of the particle number size distribution. The growth of ultrafine particles was typically observed in the afternoon. The $\mathrm{d} N / \mathrm{d} \log D_{\mathrm{p}}$ higher than $1.5 \times 10^{4} \mathrm{~cm}^{-3}$ was commonly observed in the 50-200 nm particle size range, while the $\mathrm{d} N / \mathrm{d} \log D_{\mathrm{p}}$ of super micron particles seldom exceeded $1.0 \times 10^{3} \mathrm{~cm}^{-3}$. The particle number concentration was high from 08:00 to 09:00 LT in the morning. The concentration increased again in the afternoon (about 14:00 LT), which lasted until midnight. The high concentration periods could have been caused by local traffic emissions and by secondary formation processes. Diurnal variations were also observed in the number concentrations of all particles.

Figure $2 \mathrm{c}$ depicts the mean diurnal variations of the corresponding total particle number and volume concentrations. The total number concentration started to increase after 07:00 LT until around 10:00 LT, and it reached the highest level after 14:00 LT. The particle number concentration was higher than $1.5 \times 10^{4} \mathrm{~cm}^{-3}$ before 19:00LT. After that, the number concentration decreased gradually, reaching 
Table 2. Summary of the averaged chemical characteristics of the $24 \mathrm{~h} \mathrm{PM}_{2.5}$ filter samples collected during 2015 haze events and the accordingly calculated mean $\kappa$ results of organics $(\mathrm{RH}=85 \%)$.

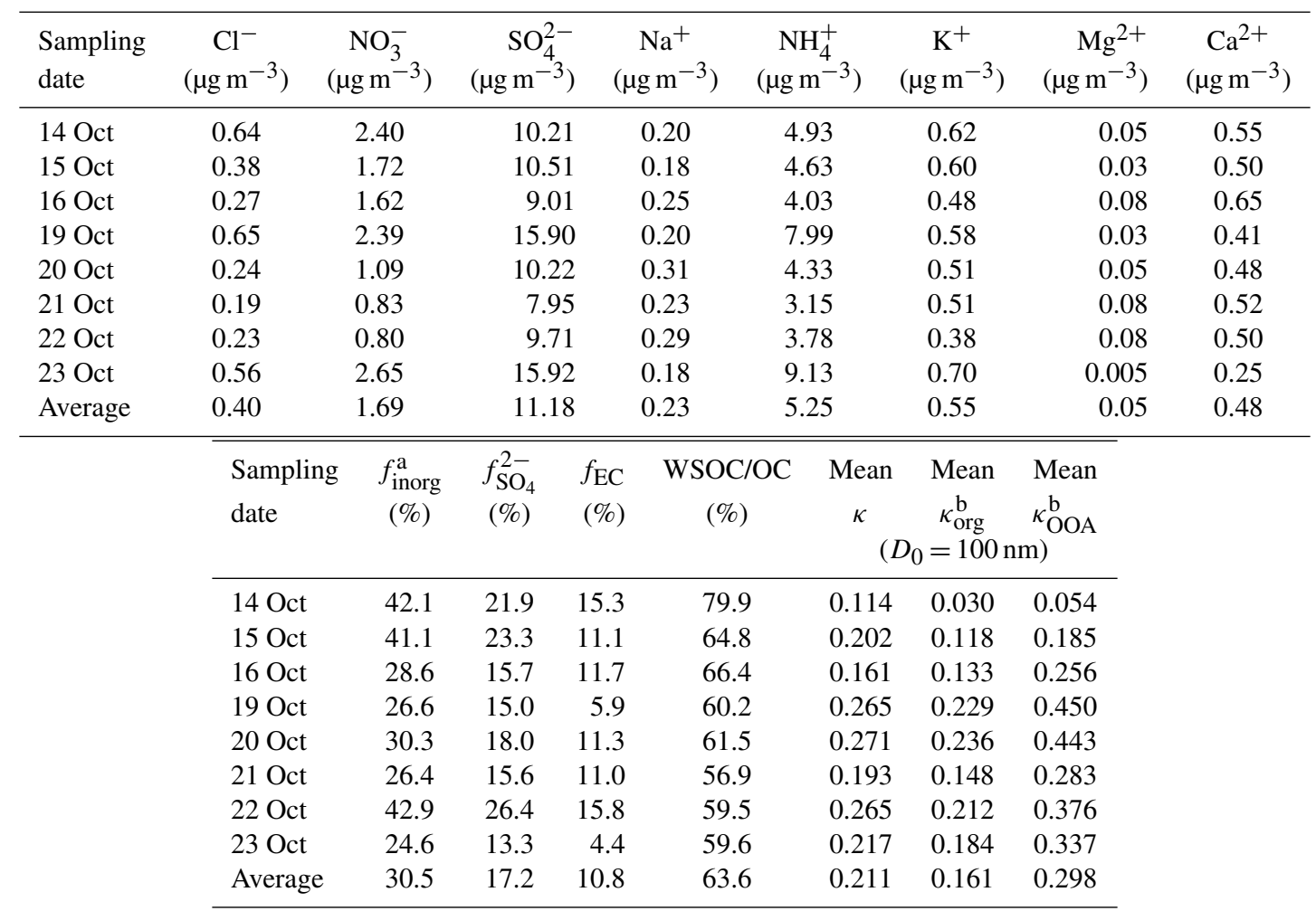

a The subscript inorg stands for all the inorganic species; hence, $f_{\text {inorg }}$ is the mass fraction of inorganic particles in the $\mathrm{PM}_{2.5}$ filter sample. All the ionic data are provided with the mean mass concentration $\left(\mu \mathrm{g} \mathrm{m}^{-3}\right){ }^{\mathrm{b}}$ The mean $\kappa$ results of organics were calculated assuming $10.0 \%$ elemental carbon (EC) in total mass (see Sect. 3.2).

$1.2 \times 10^{4} \mathrm{~cm}^{-3}$ at midnight. Correspondingly, the aerosol volume concentration was higher than $50.0 \mu^{3} \mathrm{~cm}^{-3}$ during the day. The volume concentration decreased during the night, although it was still higher than $45.0 \mu \mathrm{m}^{3} \mathrm{~cm}^{-3}$. These results demonstrate that the aerosol loading was significantly high during the period of pollution caused by wildfire haze.

\subsection{Chemical characteristics of wildfire haze particles}

Figure $3 \mathrm{a}$ and $\mathrm{b}$ show the time series of both the mass concentrations and the corresponding mass fractions of organics, sulfate, nitrate, ammonium, and chloride (expressed as $f_{\text {org }}, f_{\mathrm{SO}_{4}}^{2-}, f_{\mathrm{NO}_{3}}^{-}, f_{\mathrm{NH}_{4}}^{+}$, and $f_{\mathrm{Cl}}^{-}$, respectively) in NR-PM quantified by the ToF-ACSM. The average mass loading of NR-PM ${ }_{1}$ was as high as $44.7 \pm 24.5 \mu \mathrm{g} \mathrm{m}^{-3}$, confirming the severity of the pervasive wildfire haze. During the observation period, organics were always the most abundant compounds in NR-PM $\left(34.8 \pm 20.7 \mu \mathrm{g} \mathrm{m}^{-3}\right)$. The mass concentration of organics was higher than $50.0 \mu \mathrm{g} \mathrm{m}^{-3}$ in many cases, and it occasionally exceeded $100.0 \mu \mathrm{g} \mathrm{m}^{-3}$. On average, organics accounted for the highest mass fraction of $77.1 \%$, followed by sulfate (11.7\%), ammonium (6.4\%), and nitrate $(4.2 \%)$. The mass concentration of non-refractory chloride was almost negligible ( $0.6 \%$ of the total mass). These results demonstrate that the submicron wildfire haze particles were predominantly composed of organics.

Table 2 summarizes the mass concentrations of all the analyzed inorganic ionic species in the $\mathrm{PM}_{2.5}$ filter samples. The corresponding data for carbonaceous fractions are presented in Fig. 4. Overall, the mass fraction of EC varied from 4.4 to $15.8 \%$ with a mean value of $10.8 \%$. OC occupied 30.4 $50.7 \%$ of the total $\mathrm{PM}_{2.5}$ mass concentration, and the mean fraction was $43.0 \%$. The WSOC fraction was in the range of $17.6-30.2 \%$ with the mean level of $26.7 \%$. Correspondingly, the water-insoluble OC (WISOC) content was calculated to be $6.1-20.5 \%$ with the mean fraction of $16.3 \%$. The WSOC / OC ratios were consistently higher than $50.0 \%$ with a mean and maximum values of 63.6 and $79.9 \%$, respectively. The mean WSOC / OC value was significantly higher than that for fresh Indonesian peat burning particles emitted from the source region (i.e., 16\%; Jayaranthe et al., 2018), which were demonstrated to be generally water insoluble and thus nearly non-hygroscopic (Chen et al., 2017). This result suggests that the majority of organics in the wildfire haze particles were water soluble, implying the importance of secondary formation as well as the chemical transformation 


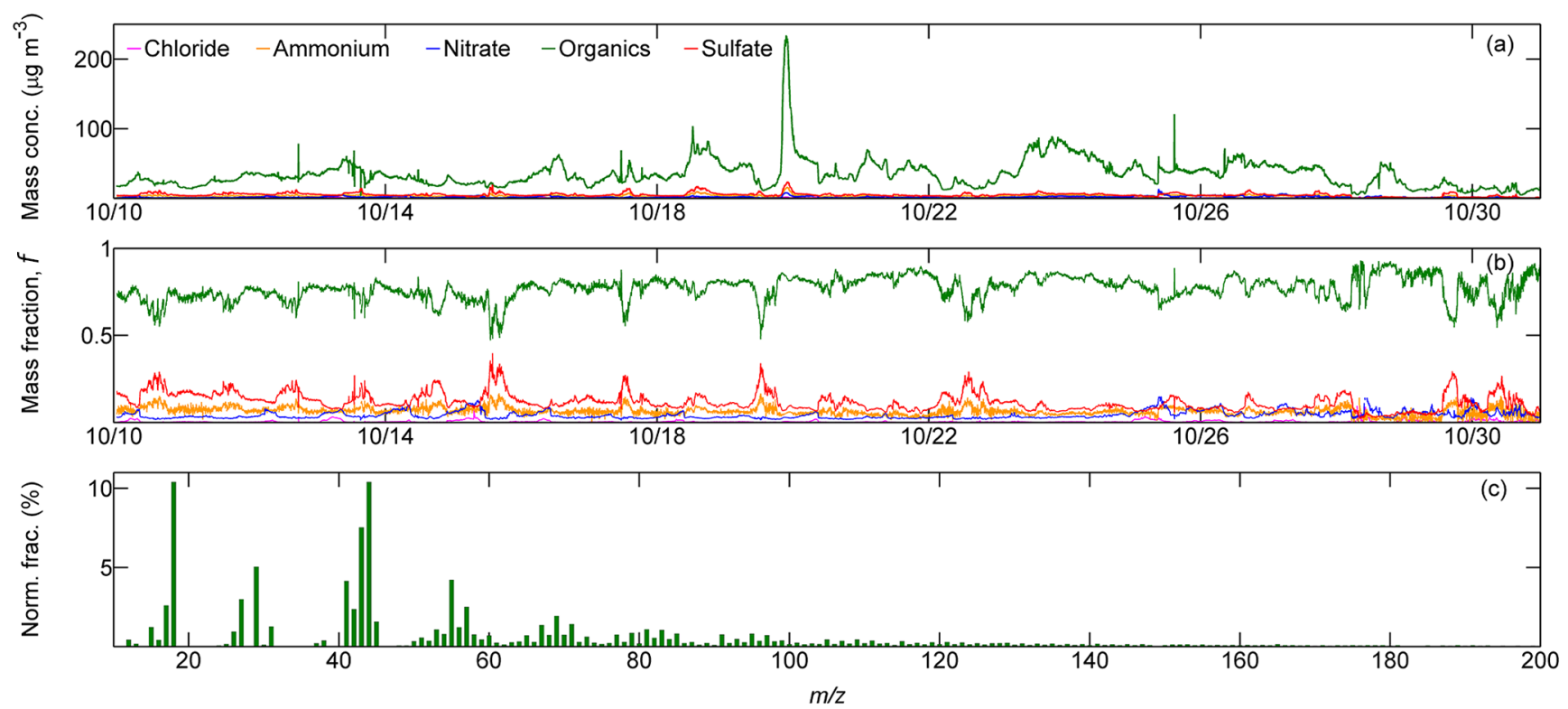

Figure 3. Time series of (a) mass concentration ("Mass conc.", $\mu \mathrm{g} \mathrm{m}^{-3}$ ) and (b) corresponding mass fraction, $f$, of the five specific chemical species in NR-PM 1 measured by ToF-ACSM (abscissa shows the observation dates in October 2015 in the date format of month day ${ }^{-1}$ ). (c) Temporally averaged OA mass spectra for submicron wildfire haze particles, displayed with the normalized ion fraction (Norm. frac., \%) of each ion fragment. Wildfire haze particles were predominantly composed of organics. Ion signals $(m / z)$ from oxygenated organics (e.g., $m / z 43,44)$ were prominent, while intensities of ions for hydrocarbon-like organic compounds (e.g., $m / z 41,55,57)$ and biomass burning tracers (e.g., $m / z 60,73)$ were relatively less intense. See the text for details.

of organic particles during atmospheric transport. Inorganic ions were less abundant and less variable than the organics were. On average, the inorganics accounted for $30.5 \%$ of the $\mathrm{PM}_{2.5}$ mass loading with the mean contributions of $0.6 \%$ by $\mathrm{Cl}^{-}, 2.6 \%$ by $\mathrm{NO}_{3}^{-}, 17.2 \%$ by $\mathrm{SO}_{4}^{2-}, 0.4 \%$ by $\mathrm{Na}^{+}, 8.1 \%$ by $\mathrm{NH}_{4}^{+}, 0.8 \%$ by $\mathrm{K}^{+}, 0.1 \%$ by $\mathrm{Mg}^{2+}$, and $0.7 \%$ by $\mathrm{Ca}^{2+}$. Sulfate, ammonium, and nitrate were the most abundant inorganic components. More than half of the inorganics was contributed by sulfate. These results show that the wildfire haze particles were dominated by organics, especially watersoluble species. Mass concentrations of organics measured by the $\mathrm{PM}_{2.5}$ filter samples and by the ToF-ACSM agreed well when the organics / OC ratio was assumed to be 1.4 (slope $=1.07 ; R^{2}=0.91$ ) (Reid et al., 2005; Hallquist et al., 2009; Levin et al., 2010). The total mass concentrations of aerosol particles quantified by the filter samples and the ToFACSM also correlated well $\left(R^{2}=0.96\right)$. The mass loading of the $\mathrm{PM}_{2.5}$ filter samples was approximately $30 \%$ higher than that of the ToF-ACSM results, likely because of the difference in particle size range and the lack of EC content for the ToF-ACSM measurements (Budisulistiorini et al., 2018).

Figure $3 \mathrm{c}$ shows the mean mass spectra of organics averaged over the observation period. Ion signals at $m / z 43$ (most likely $\mathrm{C}_{2} \mathrm{H}_{3} \mathrm{O}^{+}$) and $m / z, 44\left(\mathrm{CO}_{2}^{+}\right)$were prominent, accounting for 7.5 and $10.5 \%$ of the total organics mass spectrum. The predominant signal of $m / z 44$ indicates that organic compounds in wildfire haze particles were highly oxygenated. High-molecular-weight organic signals with $m / z>100$ possessed an abundance of $13.3 \%$. The marker ions for biomass burning particles, such as $m / z 60$ (mostly $\mathrm{C}_{2} \mathrm{H}_{4} \mathrm{O}_{2}^{+}$) and $m / z 73$ (mainly $\mathrm{C}_{3} \mathrm{H}_{5} \mathrm{O}_{2}^{+}$), which originate in levoglucosan-like species (e.g., levoglucosan, mannosan, and galactosan), were also clearly observed (Cubison et al., 2011).

Figure 6d-e show the mean contributions of four organic components classified by the ME-2 method, including HOA

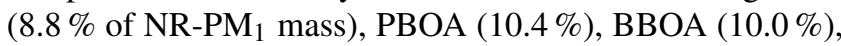
and OOA $(36.0 \%)$. The primary organics originating from biomass burning (i.e., PBOA and BBOA) accounted for $20.4 \%$. OOA was the dominant type of organics during the wildfire haze episodes.

\subsection{Hygroscopic properties of wildfire haze particles}

Figure 5 displays the time series of the mean GF data as well as the corresponding values of $\kappa$ during the entire observation period. The mean values of GF varied between 0.98 and 1.52 with the average of $1.25 \pm 0.09$. GF values larger than 1.40 were normally observed in the afternoon. The variation in the corresponding $\kappa$ results ranged from 0.004 to 0.475 , and the average $\kappa$ value was $0.189 \pm 0.087$. Table 3 summarizes the mean $\kappa$ results for organics (see Sect. 3.2, with EC considered), which were calculated using the HTDMA and ToFACSM measurements during the overlapping observation period from 10 to 24 October 2015. The HTDMA-derived bulk $\kappa$ results averaged over the same overlapping period were de- 


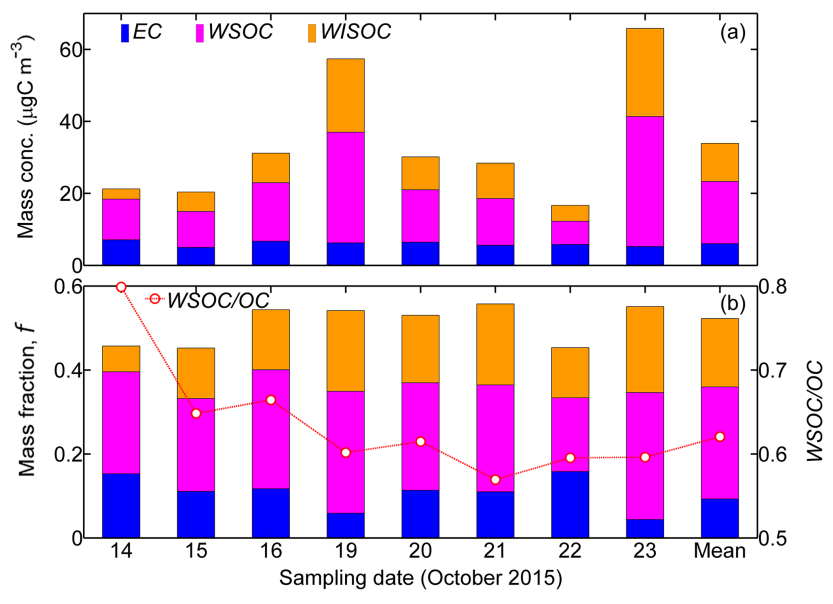

Figure 4. (a) Mass concentration ("Mass conc.", $\mu \mathrm{gCm}^{-3}$ ) and (b) corresponding mass fraction, $f$, of the carbon contents including EC, WSOC, and water-insoluble OC (WISOC) in $\mathrm{PM}_{2.5}$ filter samples. The WSOC / OC ratio is also displayed by the scattered dots in (b). All the corresponding temporal mean results are shown as "Mean". The WSOC fraction was exclusively higher than that of WISOC or EC, highlighting the dominance of WSOC in the carbon content of $\mathrm{PM}_{2.5}$ filter samples. In general, the EC fraction fluctuated around $10.0 \%$ of the total $\mathrm{PM}_{2.5}$ mass.

fined as $\kappa_{\text {HTDMA }}$. The mean $\kappa_{\text {org }}(0.157 \pm 0.108)$ was lower than the mean $\kappa_{\mathrm{OOA}}(0.266 \pm 0.184)$, as the whole organic fraction normally contains both non-hygroscopic and hygroscopic organics. The derived $\kappa_{\text {org }}$ results are demonstrated to be comparable to previously reported $\kappa$ values for bulk organics (Petters and Kreidenweis, 2007; Duplissy et al., 2011; Lathem et al., 2013; Cerully et al., 2015). Moreover, the mean $\kappa_{\mathrm{OOA}}$ value agreed well with mean $\kappa$ results in previous field and laboratory studies (e.g., $\kappa=0.25 \pm 0.06$ for biogenic OOA, Chang et al., 2010; $\kappa=0.2 \pm 0.1$ for aged BBOA, Engelhart et al., 2012). A caveat of this comparison is the representativeness of laboratory experiments for the actual environmental conditions, including types of burnt biomasses, concentrations and types of oxidants, and aging time. As the atmospheric condition of tropical Asia is unique, a systematic study of the chemical aging process of wildfire plume for the region would be required in the future. Note that the mean $\kappa_{\mathrm{OOA}}$ was even higher than the corresponding mean $\kappa_{\text {HTDMA }}(0.207 \pm 0.093)$, revealing that the water uptake particularly by some highly oxygenated organics in the wildfire haze particles could be highly significant.

\subsection{Diurnal variations of hygroscopic properties and chemical composition}

GF exhibited a clear pattern of diurnal variation (Fig. 6a). Higher GF values were observed during the daytime $(\mathrm{GF}=1.27 \pm 0.05$ for 08:00-20:00 LT). However, the values were lower in the early morning and at night $(1.23 \pm 0.05$ for 20:00-08:00 LT). The corresponding mean bulk $\kappa$ results av-

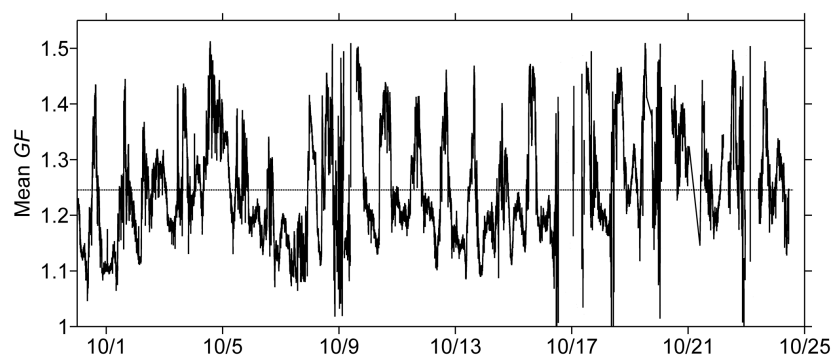

Figure 5. Time series of the volume-weighted mean particle diameter growth factor (GF) derived from HTDMA measurements (date format: month/day, 2015). The black dashed line stands for the temporal mean GF averaged over the entire observation period.

Table 3. Derived mean $\kappa$ values of organics with consideration of $10.0 \%$ EC mass fraction in total $\mathrm{NR}-\mathrm{PM}_{1}$, as well as the mean $\kappa$ results for HTDMA measurements conducted within the overlapped ToF-ACSM observation period of 10-24 October 2015 (i.e., $\kappa_{\text {HTDMA }}$ ).

\begin{tabular}{lccc}
\hline & \multicolumn{3}{c}{ Mean $\kappa($ mean \pm SD) } \\
\cline { 2 - 4 } & Overall & Daytime & Nighttime \\
\hline$\kappa_{\text {org }}$ & $0.157 \pm 0.108$ & $0.200 \pm 0.104$ & $0.103 \pm 0.086$ \\
$\kappa_{\text {OOA }}$ & $0.266 \pm 0.184$ & $0.323 \pm 0.177$ & $0.186 \pm 0.177$ \\
$\kappa_{\text {HTDMA }}$ & $0.207 \pm 0.093$ & $0.247 \pm 0.096$ & $0.160 \pm 0.063$ \\
\hline
\end{tabular}

eraged over the entire observation period were $0.213 \pm 0.051$ for the daytime and $0.172 \pm 0.043$ for nighttime.

Similarly, the daytime mean $\kappa_{\text {org }}$ and $\kappa_{\mathrm{OOA}}$ were $0.200 \pm 0.104$ and $0.323 \pm 0.177$, respectively, whereas the nighttime mean values were $0.103 \pm 0.086\left(\kappa_{\text {org }}\right)$ and $0.186 \pm 0.177\left(\kappa_{\mathrm{OOA}}\right)$ (Table 3$)$. These mean $\kappa$ values were $19.2 \%$ lower $\left(\kappa_{\mathrm{org}}\right)$ and $30.8 \%$ higher $\left(\kappa_{\mathrm{OOA}}\right)$ than the concurrently measured mean $\kappa_{\text {HTDMA }}$ result of $0.247 \pm 0.096$ (daytime), whereas they were $35.9 \%$ lower $\left(\kappa_{\text {org }}\right)$ and $16.3 \%$ higher $\left(\kappa_{\mathrm{OOA}}\right)$ than that of $0.160 \pm 0.063$ (nighttime). A more significant discrepancy between $\kappa_{\text {org }}$ and $\kappa_{\text {HTDMA }}$ was observed at night, whereas a larger difference between $\kappa_{\mathrm{OOA}}$ and $\kappa_{\text {HTDMA }}$ occurred during the day, which was likely due to the greatly inhibited oxidation processes of organic compounds in the evening in contrast to the enhanced situations during the day. This correlation could be visually observed in the corresponding diurnal patterns of both mean GF and OA factors, as the fraction of OOA was demonstrated as a moderately good indicator of the hygroscopicity of organics (Ogawa et al., 2016).

The observed variation in GF was predominantly caused by diurnal variations in the probability distribution of $g$ (Fig. 6b). Specifically, the number fractions of the more hygroscopic mode particles were low in the early morning and evening $\left(\mathrm{nf}_{\text {more }}<0.3\right)$, and higher during the afternoon (approaching the highest level of 0.6 around 15:00 LT). The value was positively correlated with $\mathrm{GF}(R=0.97)$. The 


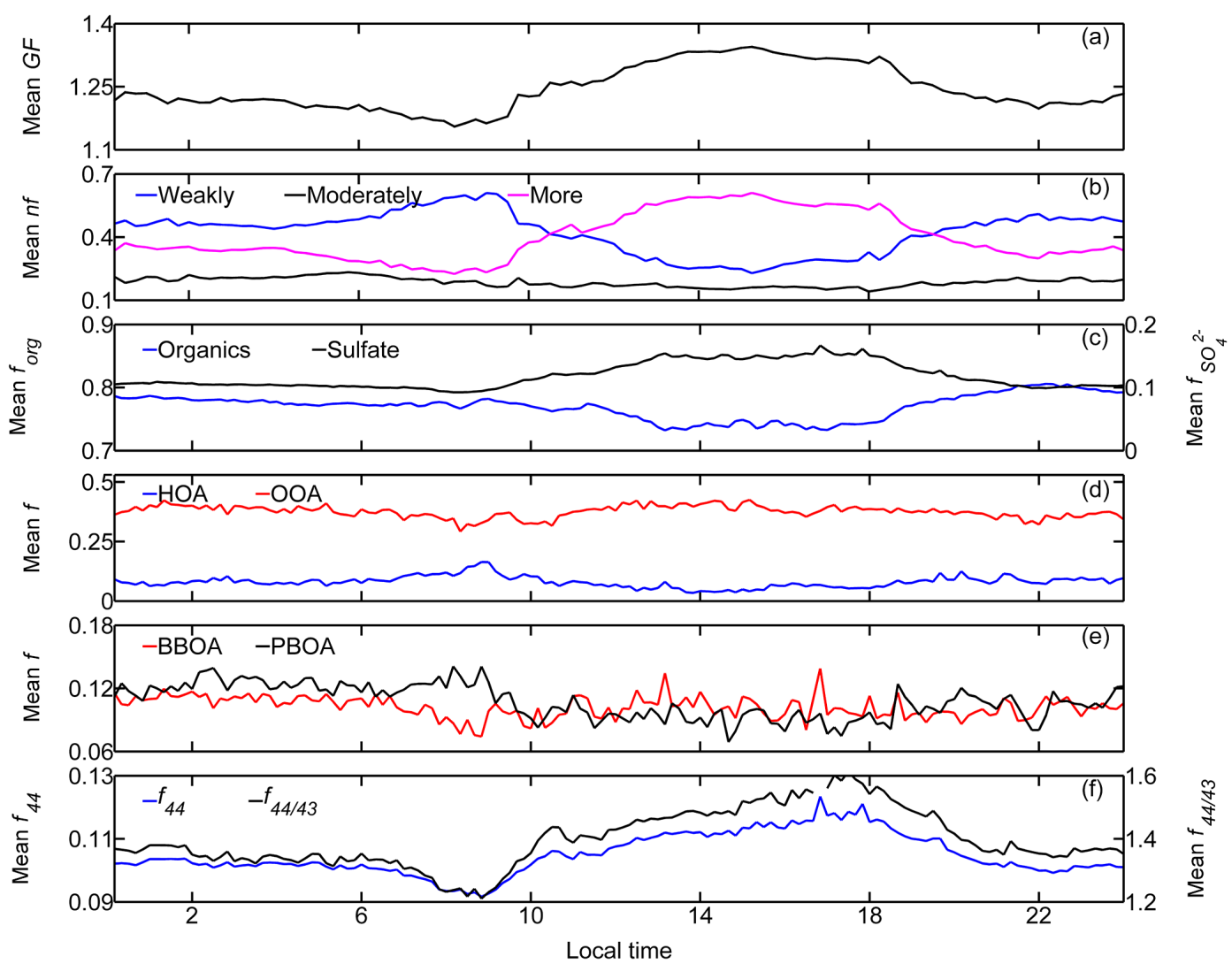

Figure 6. Temporal averaged (10-24 October 2015) diurnal variations of (a) the mean GF; (b) number fraction (nf) of the three hygroscopic modes; (c) mass fraction of the two main components in NR-PM 1 , i.e., organics $\left(f_{\text {org }}\right)$ and sulfate $\left(f_{\mathrm{SO}_{4}}^{2-}\right)$; (d, e) mass fraction of the ME-2resolved four OA factors in NR-PM 1 (i.e., $f_{\mathrm{HOA}}, f_{\mathrm{OOA}}, f_{\mathrm{BBOA}}$, and $f_{\mathrm{PBOA}}$ ); and (f) mean $f_{44}$ and $f_{44 / 43}$ of organics in NR-PM 1 (local time, LT). Pronounced diurnal patterns were observed for the mean GF, number fractions of both weakly and more hygroscopic modes, $f_{44}$, $f_{44 / 43}$, and mass fractions of organics and sulfate as well as $\mathrm{HOA}$ and $\mathrm{OOA} ; \mathrm{nf}_{\text {more }}, f_{\mathrm{SO}_{4}}^{2-}, f_{44}, f_{44 / 43}$, and $f_{\mathrm{OOA}}$ showed variations similar to that of the mean GF, whereas contrasting diurnal patterns were found for $\mathrm{nf}_{\mathrm{weakly}}, f_{\mathrm{org}}$, and $f_{\mathrm{HOA}}$.

number fraction of the weakly hygroscopic particles was opposite that of the more hygroscopic particles, and it was negatively correlated with the mean GF $(R=-0.95)$. There was no clear diurnal variation in the number fraction of the moderately hygroscopic mode particles (stable around 0.2 ). These results suggest that the water uptake by wildfire haze particles is closely related to the fractions of weakly and more hygroscopic mode particles. The mean $g$ values for each mode were $1.05 \pm 0.02$ for weakly, $1.21 \pm 0.01$ for moderately, and $1.40 \pm 0.05$ for more hygroscopic particles. The average values for $\mathrm{nf}$ were $0.42 \pm 0.18$ for weakly, $0.18 \pm 0.07$ for moderately, and $0.40 \pm 0.20$ for more hygroscopic particles (Table 4).

The diurnal variation in hygroscopic properties coincided with that in chemical compositions (Fig. 6c). The mean GF correlated well with $f_{\mathrm{SO}_{4}}^{2-}$, suggesting the primary role of $f_{\mathrm{SO}_{4}}^{2-}$ in governing the water uptake by wildfire haze particles. The enhancement of $f_{\mathrm{SO}_{4}}^{2-}$ accompanied decreased $f_{\text {org }}$. Variations in the chemical composition of organics also correlated well with the water uptake properties. The fraction
Table 4. The temporally mean number fraction (nf), volumeweighted mean diameter growth factor (GF), and $\kappa$ results (mean $\pm \mathrm{SD}$ ) of $100 \mathrm{~nm}$ wildfire haze particles in the three different hygroscopicity ranges at $85 \% \mathrm{RH}$.

\begin{tabular}{llcc}
\hline $\begin{array}{l}\text { Hygroscopic } \\
\text { mode }\end{array}$ & $\mathrm{nf}$ & $\mathrm{GF}$ & $\kappa$ \\
\hline $\begin{array}{l}\text { Weakly } \\
(g<1.15)\end{array}$ & $0.42 \pm 0.18$ & $1.05 \pm 0.02$ & $0.030 \pm 0.013$ \\
$\begin{array}{l}\text { Moderately } \\
(1.15 \leq g<1.27)\end{array}$ & $0.18 \pm 0.07$ & $1.21 \pm 0.01$ & $0.151 \pm 0.005$ \\
$\begin{array}{l}\text { More } \\
(1.27 \leq g<1.85)\end{array}$ & $0.40 \pm 0.20$ & $1.40 \pm 0.05$ & $0.343 \pm 0.054$ \\
Bulk mean & $\mathrm{n} / \mathrm{a}$ & $1.25 \pm 0.09$ & $0.189 \pm 0.087$ \\
\hline
\end{tabular}

n/a: not applicable.

of signal intensity at $m / z 44\left(f_{44}\right)$, which is considered as a marker ion for the degree of oxidation (Duplissy et al., 2011; Ng et al., 2011; Ogawa et al., 2016), was also high during the day, which was similar to the case of the mean 

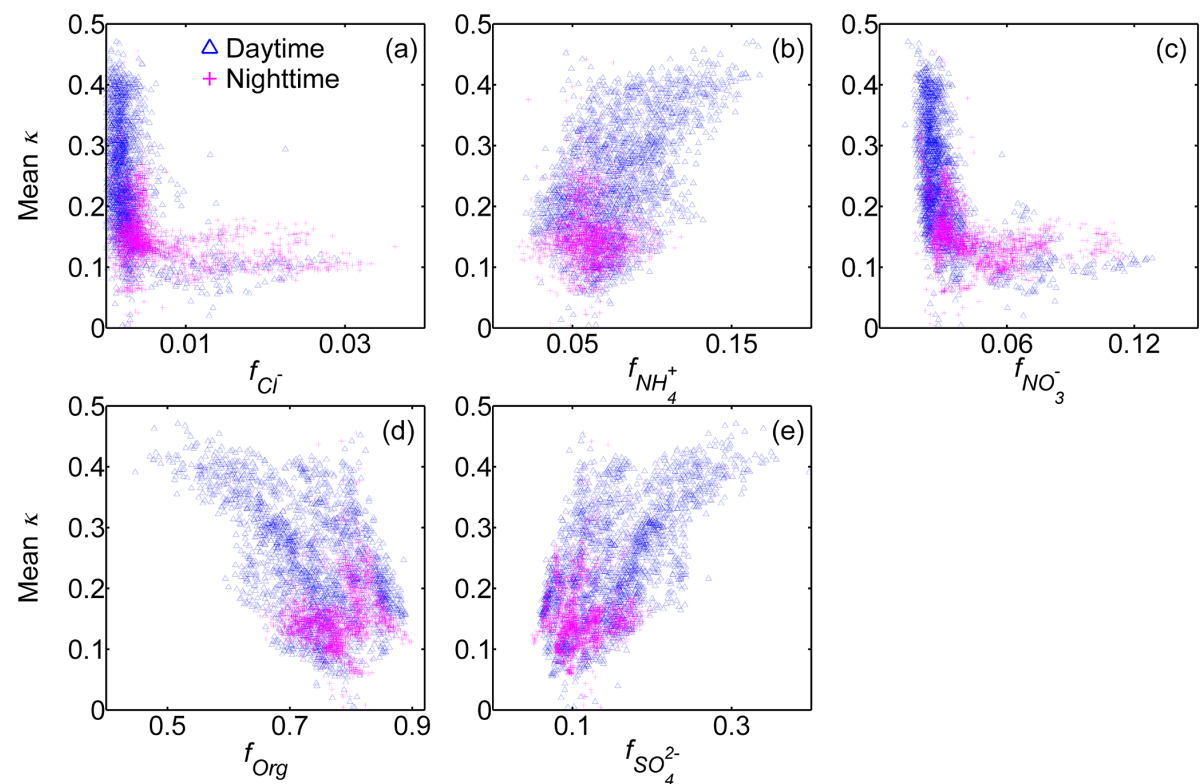

Figure 7. Relationships between the mean $\kappa$ results $(100 \mathrm{~nm})$ and the mass fractions of the five non-refractory chemical compositions of submicron wildfire haze particles.

GF and $f_{\mathrm{SO}_{4}}^{2-}$. A similar pattern was also observed in $f_{\mathrm{OOA}}$, whereas that in HOA was the opposite (Fig. 6d). For instance, $f_{\mathrm{HOA}}$ was the highest during the morning rush hours, and it subsequently decreased throughout the day. Variations in the fresh PBOA fraction $\left(f_{\mathrm{PBOA}}\right)$ were similar to those of non-peat BBOA $\left(f_{\mathrm{BBOA}}\right)$ (Fig. 6e); namely, there was no apparent diurnal pattern during the severe wildfire haze periods. Consequently, the distinctly enhanced mean GF during the day could be attributed to the increase in both $f_{\mathrm{SO}_{4}}^{2-}$ and $f_{\mathrm{OOA}}$. Additionally, the local emission, which primarily contributed to the HOA factor during morning and evening rush hours, could have decreased the mean GF during these periods. The relative importance of both local emissions and long-range transport might be influenced by meteorological conditions such as daily evolution of the planetary boundary layer (Krautstrunk et al., 2000; Geiß et al., 2017).

The diurnal variations in the organic composition were caused by the enhanced $f_{\mathrm{OOA}}$ during the day, which accompanied decreases in $f_{\mathrm{HOA}}$. In general, highly oxygenated organic compounds are highly hygroscopic due to their water solubility, qualitatively explaining the similarities in the diurnal variations among mean GF, $f_{\mathrm{OOA}}$, and $f_{44}$ (Duplissy et al., 2011; Zhao et al., 2015; Ogawa et al., 2016). The relationship between the particle hygroscopicity and the degree of oxidation of organics will be discussed in detail in Sect. 5.2.

\section{Discussion}

\subsection{Chemical composition dependences of water uptake by wildfire haze particles}

Figure 7 depicts the relationships between $\kappa$ and the mass fractions of both inorganic and organic species in NR-PM in the data obtained during the day and at night. $\kappa$ and $f_{\mathrm{SO}_{4}}^{2-}$ were positively correlated, demonstrating that sulfate was the most important compound in governing water uptake by $100 \mathrm{~nm}$ wildfire haze particles due to its high hygroscopicity. Similarly, $\kappa$ was positively related to $f_{\mathrm{NH}_{4}}^{+}$, as it is the counter cation of sulfate. In contrast, $\kappa$ was negatively correlated with $f_{\text {org }}$, as organics are less hygroscopic than inorganic salts are. There was no clear correlation between $\kappa$ and $f_{\mathrm{NO}_{3}}^{-}$, implying that the small amount of nitrate had an insignificant contribution to the variability in $\kappa$ of wildfire haze particles. $\kappa$ was almost independent of $f_{\mathrm{Cl}}^{-}$, partially due to the limited availability of non-refractory chloride. These distinctly different correlations between inorganics with mean $\kappa$ likely reflect the different formation mechanisms of these species. Sulfate formation occurs as a result of the photochemical process during the day, whereas diurnal variations in gas-particle partitioning are important for the mass concentration of nitrate or chloride (Aan de Brugh et al., 2012; Gong et al., 2013).

The correlation between $\kappa$ and $f_{\text {org }}$ was relatively scattered. For instance, $\kappa$ varied from 0.10 to 0.40 when $f_{\text {org }}$ was 0.7 , signifying that factors other than $f_{\text {org }}$ could influence the water uptake. The variability in the chemical characteristics of organics might have played a role in the scattering of the data (Fig. 6d-f). 


\subsection{Relationship between the hygroscopicity and chemical composition of organics}

Table 2 summarizes the $\kappa_{\text {org }}$ and $\kappa_{\mathrm{OOA}}$ results averaged over the same $\mathrm{PM}_{2.5}$ filter sampling periods. Figure 8 illustrates the relationship between $\kappa_{\text {org }}$ and $f_{\text {WSOC. In general, } \kappa_{\text {org }} \text { was }}$ insignificantly correlated with $f_{\mathrm{WSOC}}$, especially in the data on 22 October. The relatively high value of $f_{44}(0.11)$ on 22 October might have caused the deviation. These results indicate that the oxygenation degree of organics could predominate over the WSOC fraction regarding the hygroscopic growth of organic-rich wildfire haze particles.

Figure 9 depicts the relationships between $\kappa_{\text {org }}$ and $f_{44}$ as well as $\kappa_{\text {org }}$ and $f_{44} / f_{43}$. The daily average data were utilized. Although the data were scattered, a positive correlation between $\kappa_{\text {org }}$ and $f_{44}$ was observed $(R=0.70)$. The signal of $m / z 44$ (mostly $\mathrm{CO}_{2}^{+}$) is known to originate in highly oxidized organic functional groups, such as dicarboxylic acids and acyl peroxides (Aiken et al., 2008). These highly oxygenated functional groups contribute to promoting hygroscopicity by enhancing water solubility (Topping et al., 2005; Cubison et al., 2006; Hallquist et al., 2009; Duplissy et al., 2011; Psichoudaki and Pandis, 2013; Suda et al., 2014; Riipinen et al., 2015; Ogawa et al., 2016; Petters et al., 2016; Marsh et al., 2017). $\kappa_{\text {org }}$ and $f_{44} / f_{43}$ also presented a similar trend to that of $\kappa_{\text {org }}$ and $f_{44}$. The correlations shown in Fig. 9 clearly demonstrate the important role of oxygenation degree in the water uptake properties of organic compounds in wildfire haze particles.

During the day, organic particles tend to be highly oxidized because of the oxidation of primary organic aerosol as well as the formation of secondary organic aerosol from volatile organic compounds ( $\mathrm{Ng}$ et al., 2010 - see Fig. 6; Zhao et al., 2016). The chemical evolution processes of organic aerosol particles need to be better understood to enhance quantitative predictions of water uptake by wildfire haze particles (Kroll and Seinfeld, 2008; Riipinen et al., 2011; Winkler et al., 2012; Ehn et al., 2014). The evolution process could induce alternations in the size dependence of chemical composition and in the mixing state (Chakrabarty et al., 2006; Zhao et al., 2015). To address these unanswered questions, further knowledge about size- and mixing-statedependent chemical composition as well as the molecularlevel chemical characteristics of Indonesian wildfire haze particles are required.

\section{Conclusions}

In September-October 2015, Indonesian wildfire-induced transboundary haze pollution spread throughout Southeast Asia, affecting both the environment and climate dramatically and endangering public health and damaging the economy seriously. As a downwind receptor city, Singapore experienced pervasive wildfire haze events. In this study, we si-

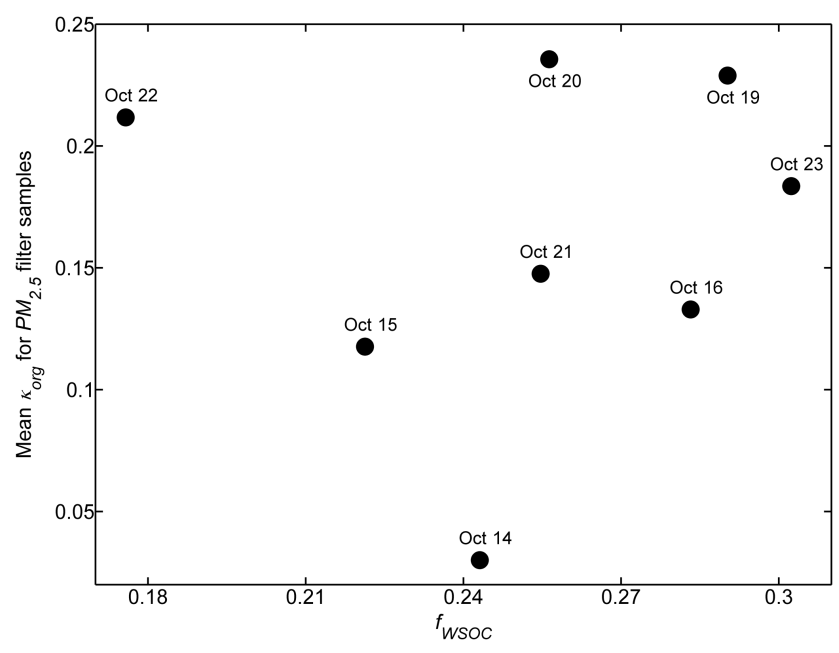

Figure 8. Correlation between the mean $\kappa$ of organics $\left(\kappa_{\text {org }}\right.$, with $10.0 \%$ EC mass fraction considered in the $\kappa$ calculation) and the mean WSOC fraction $\left(f_{\mathrm{WSOC}}\right)$ of $\mathrm{PM}_{2.5}$ filter samples.

multaneously measured the hygroscopic growth factor (GF) and the chemical composition of ambient wildfire haze particles in Singapore, with the aim of providing comprehensive insights into the linkages between water uptake and particle chemical composition as well as secondary aerosol formation.

High aerosol loading of non-refractory submicron particles $\left(\mathrm{NR}-\mathrm{PM}_{1}\right.$, occasionally exceeding $100.0 \mu \mathrm{g} \mathrm{m}^{-3}$ ) was frequently observed, stressing the severity of the 2015 wildfire haze pollution. The NR-PM 1 particles are predominantly composed of organics (OA, approximately $77.1 \%$ on average) and sulfate dominates the inorganic constituents (about $11.7 \%$ ). Chemical analyses of NR-PM ${ }_{1}$ indicate the ubiquity and dominance of oxygenated species in organics, in line with the most intense ion signals at $m / z 44$ (mostly $\mathrm{CO}_{2}^{+}$, $f_{44}=10.5 \%$ in total OA mass) and $m / z 43$ (most likely $\mathrm{C}_{2} \mathrm{H}_{3} \mathrm{O}^{+}, f_{43}=7.5 \%$ on average). Moreover, a major fraction of organics is water soluble, as signified by the high water-soluble organic carbon fraction in ambient $\mathrm{PM}_{2.5}$ filter samples ( $26.7 \%$ of the total $\mathrm{PM}_{2.5}$ mass).

Wildfire haze particles are generally highly hygroscopic. The hygroscopicity parameter, $\kappa$, of $100 \mathrm{~nm}$ particles varied between 0.004 and 0.475 , with a mean $\kappa$ value of $0.189 \pm 0.087$. The derived mean $\kappa$ results of organics were $0.157 \pm 0.108\left(\kappa_{\text {org }}\right.$, bulk organics $)$ and $0.266 \pm 0.184\left(\kappa_{\mathrm{OOA}}\right.$, oxygenated organic fraction), which are comparable to previously reported values of organic compounds (Petters and Kreidenweis, 2007; Duplissy et al., 2011; Lathem et al., 2013; Cerully et al., 2015). These results highlight the differences in $\kappa$ between wildfire haze particles and fresh Indonesian peat burning particles, which are intrinsically nonhygroscopic due to the rather limited water-soluble organic fraction (Chen et al., 2017). The GF data showed a notable diurnal variation that usually peaked during the day. This 

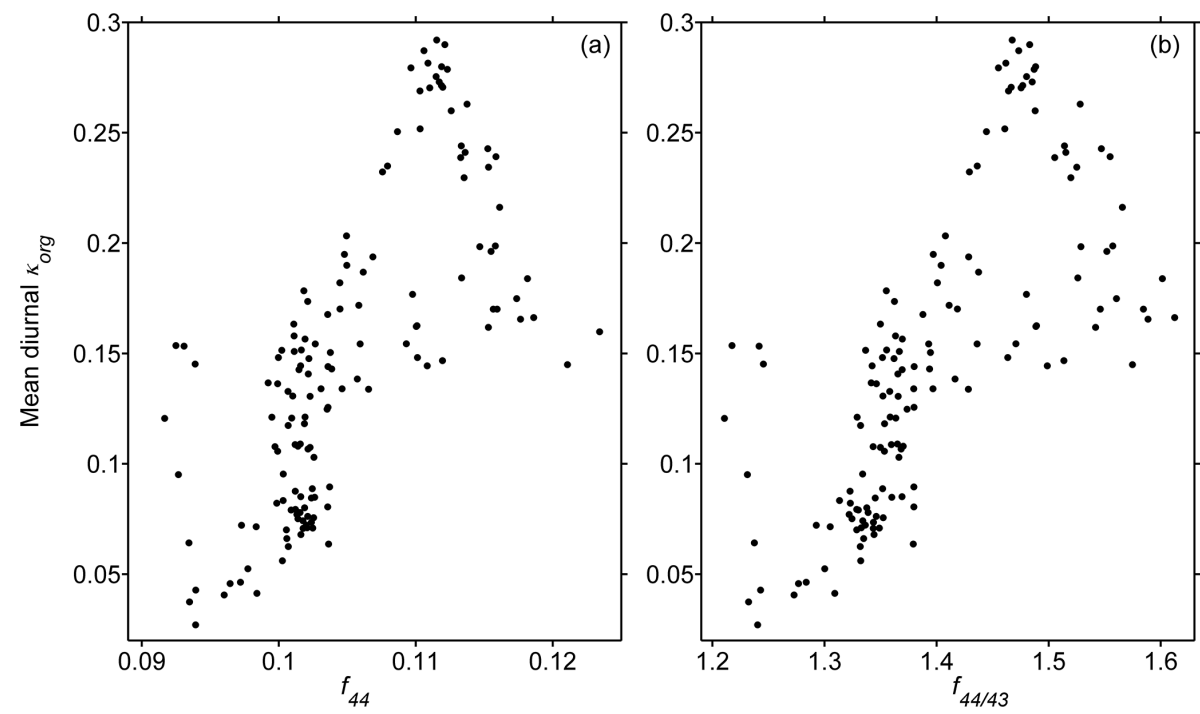

Figure 9. Relationships between the mean diurnal $\kappa_{\text {org }}$ results vs. (a) $f_{44}$ and (b) $f_{44 / 43}$ in NR-PM 1 haze particles. Mean diurnal here represents that the diurnal results for each day were further averaged over the overlapping observation period, i.e., with both HTDMA and ToF-ACSM measurements taken from 10 to 24 October 2015.

variation was identical to the diurnal pattern of the number fraction of more hygroscopic mode particles, and it accompanied the opposite fluctuation of the number fraction of weakly hygroscopic mode particles. These results imply the chemical composition dependence of particle hygroscopicity, as supported by the positive correlation of $\kappa$ with the mass fraction of sulfate but its inverse relation to the mass fraction of organics. In addition to the governing influence of sulfate, $\kappa$ of the haze particles was promoted by the water uptake of organics. Although $\kappa_{\text {org }}$ was loosely related to the water-soluble organic fraction, a positive correlation between $\kappa_{\text {org }}$ and $f_{44}$ was shown $(R=0.70)$. This denotes that the oxygenation degree of organics may play an important role in water uptake especially by organic-rich haze particles.

To the best of our knowledge, this could be the first reported field measurements of water uptake by wildfire haze particles in equatorial Asia. The results suggest that formation of secondary aerosol particles, including both inorganics and organics, is key in addressing the variability of reported results about the hygroscopic properties of aerosol particles originating from Indonesian peatland fires. Further quantitative studies on size-dependent chemical composition and detailed chemical analyses at molecular levels are needed to deepen our understanding of the water uptake by particles stemming from Indonesian wildfires.

Data availability. The data set for this publication is available upon contacting the corresponding authors.

Supplement. The supplement related to this article is available online at: https://doi.org/10.5194/acp-18-7781-2018-supplement.
Competing interests. The authors declare that they have no conflict of interest.

Acknowledgements. This work was supported by the Singapore National Research Foundation (NRF) under its Singapore National Research Fellowship scheme (National Research Fellow Award, NRF2012NRF-NRFF001-031), the NRF Campus for Research Excellence and Technological Enterprise (CREATE) program (NRF2016-ITCOO1-021), the Earth Observatory of Singapore, and Nanyang Technological University. Takuma Miyakawa and Yuichi Komazaki were funded by the Environment Research and Technology Development Fund (2-1403) of the Ministry of Environment, Japan, and the Japan Society for the Promotion of Science (JSPS), KAKENHI grant number JP26550021. We would like to thank Wen-Chien Lee and Gissella B. Lebron for assisting in the ambient haze observations. We also acknowledge the help of Pavel Adamek in revising our English.

Edited by: Manvendra K. Dubey

Reviewed by: two anonymous referees 


\section{References}

Aan de Brugh, J. M. J., Henzing, J. S., Schaap, M., Morgan, W. T., van Heerwaarden, C. C., Weijers, E. P., Coe, H., and Krol, M. C.: Modelling the partitioning of ammonium nitrate in the convective boundary layer, Atmos. Chem. Phys., 12, 3005-3023, https://doi.org/10.5194/acp-12-3005-2012, 2012.

Aiken, A. C., DeCarlo, P. F., Kroll, J. H., Worsnop, D. R., Huffman, J. A., Docherty, K. S., Ulbrich, I. M., Mohr, C., Kimmel, J. R., Sueper, D., Sun, Y., Zhang, Q., Trimborn, A., Northway, M., Ziemann, P. J., Canagaratna, M. R., Onasch, T. B., Alfarra, M. R., Prevot, A. S. H., Dommen, J., Duplissy, J., Metzger, A., Baltensperger, U., and Jimenez, J. L.: O / C and OM / OC ratios of primary, secondary, and ambient organic aerosols with high-resolution time-of-flight aerosol mass spectrometry, Environ. Sci. Technol., 42, 4478-4485, 2008.

Balasubramanian, R., Qian, W.-B., Decesari, S., Facchini, M. C., and Fuzzi, S.: Comprehensive characterization of $\mathrm{PM}_{2.5}$ aerosols in Singapore, J. Geophys. Res.-Atmos., 108, 4523, https://doi.org/10.1029/2002JD002517, 2003.

Bond, T. C. and Bergstrom, R. W.: Light absorption by carbonaceous particles: An investigative review, Aerosol Sci. Tech., 40, 27-67, 2006.

Bougiatioti, A., Bezantakos, S., Stavroulas, I., Kalivitis, N., Kokkalis, P., Biskos, G., Mihalopoulos, N., Papayannis, A., and Nenes, A.: Biomass-burning impact on CCN number, hygroscopicity and cloud formation during summertime in the eastern Mediterranean, Atmos. Chem. Phys., 16, 7389-7409, https://doi.org/10.5194/acp-16-7389-2016, 2016.

Brechtel, F. J. and Kreidenweis, S. M.: Predicting particle critical supersaturation from hygroscopic growth measurements in the humidified TDMA. Part II: laboratory and ambient studies, J. Atmos. Sci., 57, 1872-1887, 2000.

Budisulistiorini S. H., Riva, M., Williams, M., Chen, J., Itoh, M., Surratt, J. D., and Kuwata, M.: Light-absorbing brown carbon aerosol constituents from combustion of Indonesian peat and biomass, Environ. Sci. Technol., 51, 4415-4423, 2017.

Budisulistiorini, S. H., Riva, M., Williams, M., Miyakawa, T., Chen, J., Itoh, M., Surratt, J. D., and Kuwata, M.: Dominant contribution of oxygenated organic aerosol to haze particles from real-time observation in Singapore during an Indonesian wildfire event in 2015. Atmos. Chem. Phys. Discuss., https://doi.org/10.5194/acp-2018-217, in review, 2018.

Canonaco, F., Crippa, M., Slowik, J. G., Baltensperger, U., and Prévôt, A. S. H.: SoFi, an IGOR-based interface for the efficient use of the generalized multilinear engine (ME2) for the source apportionment: ME-2 application to aerosol mass spectrometer data, Atmos. Meas. Tech., 6, 3649-3661, https://doi.org/10.5194/amt-6-3649-2013, 2013.

Carrico, C. M., Petters, M. D., Kreidenweis, S. M., Collett Jr., J. L., Engling, G., and Malm, W. C.: Aerosol hygroscopicity and cloud droplet activation of extracts of filters from biomass burning experiments, J. Geophys. Res.-Atmos., 113, D08206, https://doi.org/10.1029/2007JD009274, 2008.

Carrico, C. M., Petters, M. D., Kreidenweis, S. M., Sullivan, A. P., McMeeking, G. R., Levin, E. J. T., Engling, G., Malm, W. C., and Collett Jr., J. L.: Water uptake and chemical composition of fresh aerosols generated in open burning of biomass, Atmos. Chem. Phys., 10, 5165-5178, https://doi.org/10.5194/acp10-5165-2010, 2010.
Cerully, K. M., Bougiatioti, A., Hite Jr., J. R., Guo, H., Xu, L., Ng, N. L., Weber, R., and Nenes, A.: On the link between hygroscopicity, volatility, and o xidation state of ambient and water-soluble aerosols in the southeastern United States, Atmos. Chem. Phys., 15, 8679-8694, https://doi.org/10.5194/acp15-8679-2015, 2015.

Chakrabarty, R. K., Moosmuller, H., Garro, M. A., Arnott, W. P., Walker, J., Susott, R. A., Babbitt, R. E., Wold, C. E., Lincoln, E. N., and Hao, W. M.: Emissions from the laboratory combustion of wildland fuels: Particle morphology and size, J. Geophys. Res., 111, D07204, https://doi.org/10.1029/2005JD006659, 2006.

Chan, M. N. and Chan, C. K.: Hygroscopic properties of two model humic-like substances and their mixtures with inorganics of atmospheric importance, Environ. Sci. Technol., 37, 5109-5115, 2003.

Chan, M. N., Choi, M. Y., Ng, N. L., and Chan, C. K.: Hygroscopicity of water-soluble organic compounds in atmospheric aerosols:? Amino acids and biomass burning derived organic species, Environ. Sci. Technol., 39, 1555-1562, 2005.

Chand, D., Schmid, O., Gwaze, P., Parmar, R. S., Helas, G., Zeromskiene, K., Wiedensohler, A., Massling, A., and Andreae, M. O.: Laboratory measurements of smoke optical properties from the burning of Indonesian peat and other types of biomass, Geophys. Res. Lett., 32, L12819, https://doi.org/10.1029/2005GL022678, 2005.

Chang, R. Y.-W., Slowik, J. G., Shantz, N. C., Vlasenko, A., Liggio, J., Sjostedt, S. J., Leaitch, W. R., and Abbatt, J. P. D.: The hygroscopicity parameter $(\kappa)$ of ambient organic aerosol at a field site subject to biogenic and anthropogenic influences: relationship to degree of aerosol oxidation, Atmos. Chem. Phys., 10, 5047-5064, https://doi.org/10.5194/acp-10-5047-2010, 2010.

Chen, J., Budisulistiorini, S. H., Itoh, M., Lee, W.-C., Miyakawa, T., Komazaki, Y., Yang, L. D. Q., and Kuwata, M.: Water uptake by fresh Indonesian peat burning particles is limited by watersoluble organic matter, Atmos. Chem. Phys., 17, 11591-11604, https://doi.org/10.5194/acp-17-11591-2017, 2017.

Chow, J. C., Watson, J. G., Pritchett, L. C., Pierson, W. R., Frazier, C. A., and Purcell, R. G.: The DRI thermal/optical reflectance carbon analysis system: Description, evaluation and applications in U.S. air quality studies, Atmos. Environ. A, 27, 1185-1201, 1993.

Crippa, P., Castruccio, S., Archer-Nicholls, S., Lebron, G. B., Kuwata, M., Thota, A., Sumin, S., Butt, E., Wiedinmyer, C., and Spracklen, D. V.: Population exposure to hazardous air quality due to the 2015 fires in Equatorial Asia, Sci. Rep., 6, 37074, https://doi.org/10.1038/srep37074, 2016.

Cross, E. S., Slowik, J. G., Davidovits, P., Allan, J. D., Worsnop, D. R., Jayne, J. T., Lewis, D. K., Canagaratna, M., and Onasch, T. B.: Laboratory and ambient particle density determinations using light scattering in conjunction with aerosol mass spectrometry, Aerosol Sci. Tech., 41, 343-359, 2007.

Cubison, M. J., Alfarra, M. R., Allan, J., Bower, K. N., Coe, H., McFiggans, G. B., Whitehead, J. D., Williams, P. I., Zhang, Q., Jimenez, J. L., Hopkins, J., and Lee, J.: The characterisation of pollution aerosol in a changing photochemical environment, Atmos. Chem. Phys., 6, 5573-5588, https://doi.org/10.5194/acp-65573-2006, 2006. 
Cubison, M. J., Ortega, A. M., Hayes, P. L., Farmer, D. K., Day, D., Lechner, M. J., Brune, W. H., Apel, E., Diskin, G. S., Fisher, J. A., Fuelberg, H. E., Hecobian, A., Knapp, D. J., Mikoviny, T., Riemer, D., Sachse, G. W., Sessions, W., Weber, R. J., Weinheimer, A. J., Wisthaler, A., and Jimenez, J. L.: Effects of aging on organic aerosol from open biomass burning smoke in aircraft and laboratory studies, Atmos. Chem. Phys., 11, 12049-12064, https://doi.org/10.5194/acp-11-12049-2011, 2011.

Dick, W. D., Saxena, P., and McMurry, P. H.: Estimation of water uptake by organic compounds in submicron aerosols measured during the Southeastern Aerosol and Visibility Study, J. Geophys. Res.-Atmos., 105, 1471-1479, 2000.

Dinar, E., Taraniuk, I., Graber, E. R., Anttila, T., Mentel, T. F., and Rudich, Y.: Hygroscopic growth of atmospheric and model humic-like substances, J. Geophys. Res., 112, D05211, https://doi.org/10.1029/2006JD007442, 2007.

Duncan, B. N., Bey, I., Chin, M., Mickley, L. J., Fairlie, T. D., Martin, R. V., and Matsueda, H.: Indonesian wildfires of 1997: Impact on tropospheric chemistry, J. Geophys. Res.-Atmos., 108, 4458, https://doi.org/10.1029/2002JD003195, 2003.

Duplissy, J., Gysel, M., Alfarra, M. R., Dommen, J., Metzger, A., Prévôt, A. S. H., Weingartner, E., Laaksonen, A., Raatikainen, T., Good, N., Turner, S. F., McFiggans, G., and Baltensperger, U.: Cloud forming potential of secondary organic aerosol under near atmospheric conditions, Geophys. Res. Lett., 35, L03818, https://doi.org/10.1029/2007GL031075, 2008.

Duplissy, J., DeCarlo, P. F., Dommen, J., Alfarra, M. R., Metzger, A., Barmpadimos, I., Prevot, A. S. H., Weingartner, E., Tritscher, T., Gysel, M., Aiken, A. C., Jimenez, J. L., Canagaratna, M. R., Worsnop, D. R., Collins, D. R., Tomlinson, J., and Baltensperger, U.: Relating hygroscopicity and composition of organic aerosol particulate matter, Atmos. Chem. Phys., 11, 11551165, https://doi.org/10.5194/acp-11-1155-2011, 2011.

Dusek, U., Frank, G. P., Helas, G., Iinuma, Y., Zeromskiene, K., Gwaze, P., Hennig, T., Massling, A., Schmid, O., Herrmann, H., Wiedensohler, A., and Andreae, M. O.: "Missing" cloud condensation nuclei in peat smoke, Geophys. Res. Lett., 32, L11802, https://doi.org/10.1029/2005GL022473, 2005.

Ehn, M., Thornton, J. A., Kleist, E., Sipila, M., Junninen, H., Pullinen, I., Springer, M., Rubach, F., Tillmann, R., Lee, B., LopezHilfiker, F., Andres, S., Acir, I.-H., Rissanen, M., Jokinen, T., Schobesberger, S., Kangasluoma, J., Kontkanen, J., Nieminen, T., Kurten, T., Nielsen, L. B., Jorgensen, S., Kjaergaard, H. G., Canagaratna, M., Maso, M. D., Berndt, T., Petaja, T., Wahner, A., Kerminen, V.-M., Kulmala, M., Worsnop, D. R., Wildt, J., and Mentel, T. F.: A large source of low-volatility secondary organic aerosol, Nature, 506, 476-479, 2014.

Engelhart, G. J., Hennigan, C. J., Miracolo, M. A., Robinson, A. L., and Pandis, S. N.: Cloud condensation nuclei activity of fresh primary and aged biomass burning aerosol, Atmos. Chem. Phys., 12, 7285-7293, https://doi.org/10.5194/acp12-7285-2012, 2012

Field, R. D., van der Werf, G. R., Fanin, T., Fetzer, E. J., Fuller, R., Jethva, H., Levy, R., Livesey, N. J., Luo, M., Torres, O., and Worden, H. M.: Indonesian fire activity and smoke pollution in 2015 show persistent nonlinear sensitivity to El Niño-induced drought, P. Natl. Acad. Sci. USA, 113, 9204-9209, 2016.

Fröhlich, R., Cubison, M. J., Slowik, J. G., Bukowiecki, N., Prévôt, A. S. H., Baltensperger, U., Schneider, J., Kimmel, J. R., Go- nin, M., Rohner, U., Worsnop, D. R., and Jayne, J. T.: The ToF-ACSM: a portable aerosol chemical speciation monitor with TOFMS detection, Atmos. Meas. Tech., 6, 3225-3241, https://doi.org/10.5194/amt-6-3225-2013, 2013.

Geiß, A., Wiegner, M., Bonn, B., Schäfer, K., Forkel, R., von Schneidemesser, E., Münkel, C., Chan, K. L., and Nothard, R.: Mixing layer height as an indicator for urban air quality?, Atmos. Meas. Tech., 10, 2969-2988, https://doi.org/10.5194/amt10-2969-2017, 2017.

Gong, L., Lewicki, R., Griffin, R. J., Tittel, F. K., Lonsdale, C. R., Stevens, R. G., Pierce, J. R., Malloy, Q. G. J., Travis, S. A., Bobmanuel, L. M., Lefer, B. L., and Flynn, J. H.: Role of atmospheric ammonia in particulate matter formation in Houston during summertime, Atmos. Environ., 77, 893-900, 2013.

Gras, J. L., Jensen, J. B., Okada, K., Ikegami, M., Zaizen, Y., and Makino, Y.: Some optical properties of smoke aerosol in Indonesia and tropical Australia, Geophys. Res. Lett., 26, 1393-1396, 1999.

Gunthe, S. S., King, S. M., Rose, D., Chen, Q., Roldin, P., Farmer, D. K., Jimenez, J. L., Artaxo, P., Andreae, M. O., Martin, S T., and Pöschl, U.: Cloud condensation nuclei in pristine tropical rainforest air of Amazonia: size-resolved measurements and modeling of atmospheric aerosol composition and CCN activity, Atmos. Chem. Phys., 9, 7551-7575, https://doi.org/10.5194/acp9-7551-2009, 2009.

Gysel, M., Weingartner, E., Nyeki, S., Paulsen, D., Baltensperger, U., Galambos, I., and Kiss, G.: Hygroscopic properties of water-soluble matter and humic-like organics in atmospheric fine aerosol, Atmos. Chem. Phys., 4, 35-50, https://doi.org/10.5194/acp-4-35-2004, 2004.

Gysel, M., Crosier, J., Topping, D. O., Whitehead, J. D., Bower, K. N., Cubison, M. J., Williams, P. I., Flynn, M. J., McFiggans, G. B., and Coe, H.: Closure study between chemical composition and hygroscopic growth of aerosol particles during TORCH2, Atmos. Chem. Phys., 7, 6131-6144, https://doi.org/10.5194/acp7-6131-2007, 2007.

Gysel, M., McFiggans, G. B., and Coe, H.: Inversion of tandem differential mobility analyser (TDMA) measurements, J. Aerosol Sci., 40, 134-151, 2009.

Hallar, A. G., Lowenthal, D. H., Clegg, S. L., Samburova, V., Taylor, N., Mazzoleni, L. R., Zielinska, B. K., Kristensen, T. B., Chirokova, G., McCubbin, I. B., Dodson, C., and Collins, D.: Chemical and hygroscopic properties of aerosol organics at Storm Peak Laboratory, J. Geophys. Res.-Atmos., 118, 4767-4779, 2013.

Hallquist, M., Wenger, J. C., Baltensperger, U., Rudich, Y., Simpson, D., Claeys, M., Dommen, J., Donahue, N. M., George, C., Goldstein, A. H., Hamilton, J. F., Herrmann, H., Hoffmann, T., Iinuma, Y., Jang, M., Jenkin, M. E., Jimenez, J. L., Kiendler-Scharr, A., Maenhaut, W., McFiggans, G., Mentel, Th. F., Monod, A., Prévôt, A. S. H., Seinfeld, J. H., Surratt, J. D., Szmigielski, R., and Wildt, J.: The formation, properties and impact of secondary organic aerosol: current and emerging issues, Atmos. Chem. Phys., 9, 5155-5236, https://doi.org/10.5194/acp9-5155-2009, 2009.

Huijnen, V., Wooster, M. J., Kaiser, J. W., Gaveau, D. L. A., Flemming, J., Parrington, M., Inness, A., Murdiyarso, D., Main, B., and van Weele, M.: Fire carbon emissions over maritime southeast Asia in 2015 largest since 1997, Sci. Rep., 6, 26886, https://doi.org/10.1038/srep26886, 2016. 
Jayarathne, T., Stockwell, C. E., Gilbert, A. A., Daugherty, K., Cochrane, M. A., Ryan, K. C., Putra, E. I., Saharjo, B. H., Nurhayati, A. D., Albar, I., Yokelson, R. J., and Stone, E. A.: Chemical characterization of fine particulate matter emitted by peat fires in Central Kalimantan, Indonesia, during the 2015 El Niño, Atmos. Chem. Phys., 18, 2585-2600, https://doi.org/10.5194/acp-18-2585-2018, 2018.

Jimenez, J. L., Canagaratna, M. R., Donahue, N. M., Prevot, A. S. H., Zhang, Q., Kroll, J. H., DeCarlo, P. F., Allan, J. D., Coe, H., Ng, N. L., Aiken, A. C., Docherty, K. S., Ulbrich, I. M., Grieshop, A. P., Robinson, A. L., Duplissy, J., Smith, J. D., Wilson, K. R., Lanz, V. A., Hueglin, C., Sun, Y. L., Tian, J., Laaksonen, A., Raatikainen, T., Rautiainen, J., Vaattovaara, P., Ehn, M., Kulmala, M., Tomlinson, J. M., Collins, D. R., Cubison, M. J., Dunlea, J., Huffman, J. A., Onasch, T. B., Alfarra, M. R., Williams, P. I., Bower, K., Kondo, Y., Schneider, J., Drewnick, F., Borrmann, S., Weimer, S., Demerjian, K., Salcedo, D., Cottrell, L., Griffin, R., Takami, A., Miyoshi, T., Hatakeyama, S., Shimono, A., Sun, J. Y, Zhang, Y. M., Dzepina, K., Kimmel, J. R., Sueper, D., Jayne, J. T., Herndon, S. C., Trimborn, A. M., Williams, L. R., Wood, E. C., Middlebrook, A. M., Kolb, C. E., Baltensperger, U., and Worsnop, D. R.: Evolution of organic aerosols in the atmosphere, Science, 326, 1525-1529, 2009.

Johnston, F. H., Henderson, S. B., Chen, Y., Randerson, J. T., Marlier, M., DeFries, R. S., Kinney, P., Bowman, D. M., and Brauer, M.: Estimated global mortality attributable to smoke from landscape fires, Environ. Health Perspect., 120, 695-701, 2012.

Keywood, M. D., Ayers, G. P., Gras, J. L., Boers, C. P., and Leong: Haze in the Klang Valley of Malaysia, Atmos. Chem. Phys., 3, 591-605, https://doi.org/10.5194/acp-3-591-2003, 2003.

King, S. M., Rosenoern, T., Shilling, J. E., Chen, Q., and Martin, S. T.: Cloud condensation nucleus activity of secondary organic aerosol particles mixed with sulfate, Geophys. Res. Lett., 34, L24806, https://doi.org/10.1029/2007GL030390, 2007.

Konecny, K., Ballhorn, U., Navratil, P., Jubanski, J., Page, S. E., Tansey, K., Hooijer, A., Vernimmen, R., and Siegert, F.: Variable carbon losses from recurrent fires in drained tropical peatlands, Global Change Biol., 22, 1469-1480, 2016.

Koplitz, S. N., Mickley, L. J., Marlier, M. E., Buonocore, J. J., Kim, P. S., Liu, T., Sulprizio, M. P., DeFries, R. S., Jacob, D. J., Schwartz, J., Pongsiri, M., and Myers, S. S.: Public health impacts of the severe haze in Equatorial Asia in SeptemberOctober 2015: demonstration of a new framework for informing fire management strategies to reduce downwind smoke exposure, Environ. Res. Lett., 11, 094023, https://doi.org/10.1088/17489326/11/9/094023, 2016.

Krautstrunk, M., Neumann-Hauf, G., Schlager, H., Klemm, O., Beyrich, F., Corsmeier, U., Kalthoff, N., and Kotzian, M.: An experimental study on the planetary boundary layer transport of air pollutants over East Germany, Atmos. Environ., 34, 1247-1266, 2000.

Kreidenweis, S. M., Petters, M. D., and DeMott, P. J.: Singleparameter estimates of aerosol water content, Environ. Res. Lett., 3, 035002, https://doi.org/10.1088/1748-9326/3/3/035002, 2008.

Kristensen, T. B., Wex, H., Nekat, B., Nøjgaard, J. K., van Pinxteren, D., Lowenthal, D. H., Mazzoleni, L. R., Dieckmann, K., Bender Koch, C., Mentel, T. F., Herrmann, H., Hallar, A. G., Stratmann, F., and Bilde, M.: Hygroscopic growth and CCN activity of HULIS from different environments, J. Geophys. Res.-
Atmos., 117, D22203, https://doi.org/10.1029/2012JD018249, 2012.

Kroll, J. H. and Seinfeld, J. H.: Chemistry of secondary organic aerosol: Formation and evolution of low-volatility organics in the atmosphere, Atmos. Environ., 42, 3593-3624, 2008.

Kunii, O., Kanagawa, S., Yajima, I., Hisamatsu, Y., Yamamura, S., Amagai, T., and Ismail, T. S.: The 1997 haze disaster in Indonesia: Its air quality and health effects, Arch. Environ. Health Int. J., 57, 16-22, 2002.

Kuwata, M., Zorn, S. R., and Martin, S. T.: Using elemental ratios to predict the density of organic material composed of carbon, hydrogen, and oxygen, Environ. Sci. Technol., 46, 787-794, 2012.

Langner, A., Miettinen, J., and Siegert, F.: Land cover change 20022005 in Borneo and the role of fire derived from MODIS imagery, Global Change Biol., 13, 2329-2340, 2007.

Lathem, T. L., Beyersdorf, A. J., Thornhill, K. L., Winstead, E. L., Cubison, M. J., Hecobian, A., Jimenez, J. L., Weber, R. J., Anderson, B. E., and Nenes, A.: Analysis of CCN activity of Arctic aerosol and Canadian biomass burning during summer 2008, Atmos. Chem. Phys., 13, 2735-2756, https://doi.org/10.5194/acp13-2735-2013, 2013.

Lelieveld, J., Evans, J. S., Fnais, M., Giannadaki, D., and Pozzer, A.: The contribution of outdoor air pollution sources to premature mortality on a global scale, Nature, 525, 367-371, 2015.

Levin, E. J. T., McMeeking, G. R., Carrico, C. M., Mack, L., Kreidenweis, S. M., Wold, C. E., Moosmueller, H., Arnott, W. P., Hao, W. M., Collett, J. L., and Malm, W. C.: Biomass burning smoke aerosol properties measured during FLAME 2, J. Geophys. Res., 115, D18210, https://doi.org/10.1029/2009JD013601, 2010.

Lin, N.-H., Tsay, S.-C., Maring, H. B., Yen, M.-C., Sheu, G.-R., Wang, S.-H., Chi, K. H., Chuang, M.-T., Ou-Yang, C.-F., Fu, J. S., Reid, J. S., Lee, C.-T., Wang, L.-C., Wang, J.-L., Hsu, C. N., Sayer, A. M., Holben, B. N., Chu, Y.-C., Nguyen, X. A., Sopajaree, K., Chen, S.-J., Cheng, M.-T., Tsuang, B.-J., Tsai, C.-J., Peng, C.-M., Schnell, R. C., Conway, T., Chang, C.-T., Lin, K.S., Tsai, Y. I., Lee, W.-J., Chang, S.-C., Liu, J.-J., Chiang, W.-L., Huang, S.-J., Lin, T.-H., and Liu, G.-R.: An overview of regional experiments on biomass burning aerosols and related pollutants in Southeast Asia: From BASE-ASIA and the Dongsha Experiment to 7-SEAS, Atmos. Environ., 78, 1-19, 2013.

Marlier, M. E., DeFries, R. S., Voulgarakis, A., Kinney, P. L., Randerson, J. T., Shindell, D. T., Chen, Y., and Faluvegi, G.: El Niño and health risks from landscape fire emissions in southeast Asia, Nat. Clim. Change, 3, 131-136, 2013.

Marlier, M. E., DeFries, R., Pennington, D., Nelson, E., Ordway, E. M., Lewis, J., Koplitz, S. N., and Mickley, L. J.: Future fire emissions associated with projected land use change in Sumatra, Global Change Biol., 21, 345-362, 2015.

Marsh, A., Miles, R. E. H., Rovelli, G., Cowling, A. G., Nandy, L., Dutcher, C. S., and Reid, J. P.: Influence of organic compound functionality on aerosol hygroscopicity: dicarboxylic acids, alkyl-substituents, sugars and amino acids, Atmos. Chem. Phys., 17, 5583-5599, https://doi.org/10.5194/acp17-5583-2017, 2017.

Massoli, P., Lambe, A. T., Ahern, A. T., Williams, L. R., Ehn, M., Mikkilä, J., Canagaratna, M. R., Brune, W. H., Onasch, T. B., Jayne, J. T., Petäjä, T., Kulmala, M., Laaksonen, A., Kolb, C. E., Davidovits, P., and Worsnop, D. R.: Relationship between 
aerosol oxidation level and hygroscopic properties of laboratory generated secondary organic aerosol (SOA) particles, Geophys. Res. Lett., 37, L24801, https://doi.org/10.1029/2010GL045258, 2010.

Mircea, M., Facchini, M. C., Decesari, S., Cavalli, F., Emblico, L., Fuzzi, S., Vestin, A., Rissler, J., Swietlicki, E., Frank, G., Andreae, M. O., Maenhaut, W., Rudich, Y., and Artaxo, P.: Importance of the organic aerosol fraction for modeling aerosol hygroscopic growth and activation: a case study in the Amazon Basin, Atmos. Chem. Phys., 5, 3111-3126, https://doi.org/10.5194/acp5-3111-2005, 2005.

Ng, N. L., Canagaratna, M. R., Zhang, Q., Jimenez, J. L., Tian, J., Ulbrich, I. M., Kroll, J. H., Docherty, K. S., Chhabra, P. S., Bahreini, R., Murphy, S. M., Seinfeld, J. H., Hildebrandt, L., Donahue, N. M., DeCarlo, P. F., Lanz, V. A., Prévôt, A. S. H., Dinar, E., Rudich, Y., and Worsnop, D. R.: Organic aerosol components observed in Northern Hemispheric datasets from Aerosol Mass Spectrometry, Atmos. Chem. Phys., 10, 46254641, https://doi.org/10.5194/acp-10-4625-2010, 2010.

Ng, N. L., Canagaratna, M. R., Jimenez, J. L., Chhabra, P. S., Seinfeld, J. H., and Worsnop, D. R.: Changes in organic aerosol composition with aging inferred from aerosol mass spectra, Atmos. Chem. Phys., 11, 6465-6474, https://doi.org/10.5194/acp11-6465-2011, 2011.

Ogawa, S., Setoguchi, Y., Kawana, K., Nakayama, T., Ikeda, Y., Sawada, Y., Matsumi, Y., and Mochida, M.: Hygroscopicity of aerosol particles and $\mathrm{CCN}$ activity of nearly hydrophobic particles in the urban atmosphere over Japan during summer, J. Geophys. Res.-Atmos., 121, 7215-7234, 2016.

Page, S., Hoscilo, A., Langner, A., Tansey, K., Siegert, F., Limin, S., and Rieley, J.: Tropical peatland fires in Southeast Asia, in: Tropical Fire Ecology: Climate Change, Land Use and Ecosystem Dynamics, edited by: Cochrane, M. A., Springer-Praxis, Heidelberg, Germany, 263-287, 2009.

Page, S. E., Siegert, F., Rieley, J. O., Boehm, H.-D. V., Jaya, A., and Limin, S.: The amount of carbon released from peat and forest fires in Indonesia during 1997, Nature, 420, 61-65, 2002.

Park, K., Kittelson, D. B., Zachariah, M. R., and McMurry, P. H.: Measurement of inherent material density of nanoparticle agglomerates, J. Nanopart. Res., 6, 267-272, 2004.

Peng, C., Chan, M. N., and Chan, C. K.: The hygroscopic properties of dicarboxylic and multifunctional acids: Measurements and UNIFAC predictions, Environ. Sci. Technol., 35, 4495-4501, 2001.

Petters, M. D. and Kreidenweis, S. M.: A single parameter representation of hygroscopic growth and cloud condensation nucleus activity, Atmos. Chem. Phys., 7, 1961-1971, https://doi.org/10.5194/acp-7-1961-2007, 2007.

Petters, M. D., Carrico, C. M., Kreidenweis, S. M., Prenni, A. J., DeMott, P. J., Collett r., J. L., and Moosmuller, H.: Cloud condensation nucleation activity of biomass burning aerosol, J. Geophys. Res.-Atmos., 114, D22205, https://doi.org/10.1029/2009JD012353, 2009.

Petters, M. D., Kreidenweis, S. M., and Ziemann, P. J.: Prediction of cloud condensation nuclei activity for organic compounds using functional group contribution methods, Geosci. Model Dev., 9, 111-124, https://doi.org/10.5194/gmd-9-111-2016, 2016.
Psichoudaki, M. and Pandis, S. N.: Atmospheric aerosol watersoluble organic carbon measurement: A theoretical analysis, Environ. Sci. Technol., 47, 9791-9798, 2013.

Reid, J. S., Koppmann, R., Eck, T. F., and Eleuterio, D. P.: A review of biomass burning emissions part II: intensive physical properties of biomass burning particles, Atmos. Chem. Phys., 5, 799825, https://doi.org/10.5194/acp-5-799-2005, 2005.

Reid, J. S., Hyer, E. J., Johnson, R. S., Holben, B. N., Yokelson, R. J., Zhang, J., Campbell, J. R., Christopher, S. A., Girolamo, L. D., Giglio, L., Holz, R. E., Kearney, C., Miettinen, J., Reid, E. A., Turk, F. J., Wang, J., Xian, P., Zhao, G., Balasubramanian, R., Chew, B. N., Janjai, S., Lagrosas, N., Lestari, P., Lin, N.-H., Mahmud, M., Nguyen, A. X., Norris, B., Oanh, N. T. K., Oo, M., Salinas, S. V., Welton, E. J., and Liew, S. C.: Observing and understanding the Southeast Asian aerosol system by remote sensing: An initial review and analysis for the Seven Southeast Asian Studies (7SEAS) program, Atmos. Res., 122, 403-468, 2013.

Riipinen, I., Pierce, J. R., Yli-Juuti, T., Nieminen, T., Häkkinen, S., Ehn, M., Junninen, H., Lehtipalo, K., Petäjä, T., Slowik, J., Chang, R., Shantz, N. C., Abbatt, J., Leaitch, W. R., Kerminen, V.-M., Worsnop, D. R., Pandis, S. N., Donahue, N. M., and Kulmala, M.: Organic condensation: a vital link connecting aerosol formation to cloud condensation nuclei (CCN) concentrations, Atmos. Chem. Phys., 11, 3865-3878, https://doi.org/10.5194/acp-11-3865-2011, 2011.

Riipinen, I., Rastak, N., and Pandis, S. N.: Connecting the solubility and $\mathrm{CCN}$ activation of complex organic aerosols: a theoretical study using solubility distributions, Atmos. Chem. Phys., 15, 6305-6322, https://doi.org/10.5194/acp-15-6305-2015, 2015.

Rose, D., Nowak, A., Achtert, P., Wiedensohler, A., Hu, M., Shao, M., Zhang, Y., Andreae, M. O., and Pöschl, U.: Cloud condensation nuclei in polluted air and biomass burning smoke near the mega-city Guangzhou, China - Part 1: Size-resolved measurements and implications for the modeling of aerosol particle hygroscopicity and CCN activity, Atmos. Chem. Phys., 10, 33653383, https://doi.org/10.5194/acp-10-3365-2010, 2010.

Rosenfeld, D.: TRMM observed first direct evidence of smoke from forest fires inhibiting rainfall, Geophys. Res. Lett., 26, 31053108, 1999.

Saxena, E., Hildemann, L. M., McMurry, E. H., and Seinfeld, J. H.: Organics alter hygroscopic behavior of atmospheric particles, J. Geophys. Res., 100, 18755-18770, 1995.

See, S. W., Balasubramanian, R., and Wang, W.: A study of the physical, chemical, and optical properties of ambient aerosol particles in Southeast Asia during hazy and nonhazy days, J. Geophys. Res.-Atmos., 111, D10S08, https://doi.org/10.1029/2005JD006180, 2006.

Spracklen, D. V., Reddington, C. L., and Gaveau, D. L. A.: Industrial concessions, fires and air pollution in Equatorial Asia, Environ. Res. Lett., 10, 091001, https://doi.org/10.1088/17489326/10/9/091001, 2015.

Stockwell, C. E., Jayarathne, T., Cochrane, M. A., Ryan, K. C., Putra, E. I., Saharjo, B. H., Nurhayati, A. D., Albar, I., Blake, D. R., Simpson, I. J., Stone, E. A., and Yokelson, R. J.: Field measurements of trace gases and aerosols emitted by peat fires in Central Kalimantan, Indonesia, during the 2015 El Niño, Atmos. Chem. Phys., 16, 11711-11732, https://doi.org/10.5194/acp-16-117112016, 2016. 
Stokes, R. H. and Robinson, R. A.: Interactions in aqueous nonelectrolyte solutions: I. Solute-solvent equilibria, J. Phys. Chem., 70, 2126-2130, 1966.

Suda, S. R., Petters, M. D., Yeh, G. K., Strollo, C., Matsunaga, A., Faulhaber, A., Ziemann, P. J., Prenni, A. J., Carrico, C. M., Sullivan, R. C., and Kreidenweis, S. M.: Influence of functional groups on organic aerosol cloud condensation nucleus activity, Environ. Sci. Technol., 48, 10182-10190, 2014.

Topping, D. O., McFiggans, G. B., and Coe, H.: A curved multicomponent aerosol hygroscopicity model framework: Part 2 - Including organic compounds, Atmos. Chem. Phys., 5, 1223-1242, https://doi.org/10.5194/acp-5-1223-2005, 2005.

Turpin, B. J., Hering, S. V., and Huntzicker, J. J.: Investigation of organic aerosol sampling artifacts in the Los Angeles Basin, Atmos. Environ., 28, 3061-3071, 1994.

van der Werf, G. R., Randerson, J. T., Giglio, L., Collatz, G. J., Mu, M., Kasibhatla, P. S., Morton, D. C., DeFries, R. S., Jin, Y., and van Leeuwen, T. T.: Global fire emissions and the contribution of deforestation, savanna, forest, agricultural, and peat fires (1997-2009), Atmos. Chem. Phys., 10, 11707-11735, https://doi.org/10.5194/acp-10-11707-2010, 2010.

Whitehead, J. D., Irwin, M., Allan, J. D., Good, N., and McFiggans, G.: A meta-analysis of particle water uptake reconciliation studies, Atmos. Chem. Phys., 14, 11833-11841, https://doi.org/10.5194/acp-14-11833-2014, 2014.

Whitehead, J. D., Darbyshire, E., Brito, J., Barbosa, H. M. J., Crawford, I., Stern, R., Gallagher, M. W., Kaye, P. H., Allan, J. D., Coe, H., Artaxo, P., and McFiggans, G.: Biogenic cloud nuclei in the central Amazon during the transition from wet to dry season, Atmos. Chem. Phys., 16, 9727-9743, https://doi.org/10.5194/acp-16-9727-2016, 2016.
Winkler, P. M., Ortega, J., Karl, T., Cappellin, L., Friedli, H. R., Barsanti, K., McMurry, P. H., and Smith, J. N.: Identification of the biogenic compounds responsible for sizedependent nanoparticle growth, Geophys. Res. Lett., 39, L20815, https://doi.org/10.1029/2012GL053253, 2012.

World Health Organization: Global Health Risks: Mortality and Burden of Disease Attributable to Select Major Risks (Geneva, Switzerland: World Health Organization), available at: http://www.who.int/healthinfo/global_burden_disease/ GlobalHealthRisks_report_full.pdf (last access: 24 April 2017), 2009.

Zhao, D. F., Buchholz, A., Kortner, B., Schlag, P., Rubach, F., Kiendler-Scharr, A., Tillmann, R., Wahner, A., Flores, J. M., Rudich, Y., Watne, A. K., Hallquist, M., Wildt, J., and Mentel, Th F.: Size-dependent hygroscopicity parameter $(\kappa)$ and chemical composition of secondary organic cloud condensation nuclei, Geophys. Res. Lett., 42, 10920-10928, 2015.

Zhao, D. F., Buchholz, A., Kortner, B., Schlag, P., Rubach, F., Fuchs, H., Kiendler-Scharr, A., Tillmann, R., Wahner, A., Watne, ̊. K., Hallquist, M., Flores, J. M., Rudich, Y., Kristensen, K., Hansen, A. M. K., Glasius, M., Kourtchev, I., Kalberer, M., and Mentel, Th. F.: Cloud condensation nuclei activity, droplet growth kinetics, and hygroscopicity of biogenic and anthropogenic secondary organic aerosol (SOA), Atmos. Chem. Phys., 16, 1105-1121, https://doi.org/10.5194/acp16-1105-2016, 2016. 